\title{
Screening, Cloning, Enzymatic Properties of A Novel Thermostable Cellulase Enzyme and Its Potential Application on Water Hyacinth Utilization
}

\section{Xiaoshen Zhao ( 1170001807@qq.com )}

Guangdong Pharmaceutical University

Liyang Liu

Guangdong Pharmaceutical University

\section{Zujun Deng}

Guangdong Pharmaceutical Universsity

Shan Liu

Guangzhou Basic Clean cosmetics Manfacturing Co. Ltd.

Jeonyun Yun

Guangzhou Basic Clean Cosmetics Manufacturing Co. Itd.

\section{Xiong Xiao}

Guangzhou Basic Clean Cosmetics Manufacturing Co. Ltd.

He Li

Guangdong Pharmaceutical University

\section{Research Article}

Keywords: Biotransformation, Cellulase, Metagenomic library, Thermostability, Water hyacinth

Posted Date: February 18th, 2021

DOI: https://doi.org/10.21203/rs.3.rs-206402/v1

License: (c) (1) This work is licensed under a Creative Commons Attribution 4.0 International License.

Read Full License

Version of Record: A version of this preprint was published at International Microbiology on March 8th, 2021. See the published version at https://doi.org/10.1007/s10123-021-00170-4. 


\section{Abstract}

Cellulose is the cheapest, natural, renewable organic substance that is used as a carbon source in various fields. Water hyacinth, an aquatic plant rich in cellulose, is often used as a raw material in fuel production. However, natural cellulase can be hardly used in industrial production on account of its low thermal stability and activity. In this study, a metagenomic library was constructed. Then a new cellulase gene, cel1029, was screened by Congo red staining and expressed in the prokaryotic system. Enzymatic properties of $\mathrm{Ce} / 1029$ were explored, including optimum temperature and $\mathrm{pH}$, thermal and $\mathrm{pH}$ stability, and tolerance against organic solvents, metal ions and salt solutions. Finally, its ability of degrading water hyacinth was identified and evaluated. Cel1029 displayed high homology with endoglucanase in the glycoside hydrolase family 5 (GH5) and had high stability across a broad temperature range. More than $86 \%$ of its enzymatic activities were retained between 4 and $60^{\circ} \mathrm{C}$ after $24 \mathrm{~h}$ of incubation. Singlefactor analysis and orthogonal design were further conducted to determine the optimal conditions for the highest reducing sugar yield of water hyacinth. Interestingly, Cel1029 efficiently transformed water hyacinth with a reducing sugar yield of $430.39 \mathrm{mg} / \mathrm{g}$ in $22 \mathrm{~h}$. These findings may open the door for significant industrial applications of a novel GH5 cellulase (NCBI Reference Sequence: MK051001, Ce/1029) and help identify more efficient methods to degrade cellulose-rich plants.

\section{Introduction}

Cellulase, including endoglucanase (endo-1,4-D-glueanase, EC3.2.1.4), exoglucanase (exo-1,4-Dglucanase, EC3.2.1.91) and glucosidase (1,4-D-glueosidase, EC3.2.1.21), is a type of enzymes that can hydrolyze the $\beta-1$,4-glycosidic bond between cellulose molecules (Lin et al. 2016). Endocellulase mainly catalyzes degradation of the amorphous region in cellulose, providing the starting site for further catalysis of exocellulase, so it plays an important role in efficient degradation of cellulose. Cellulase is distributed in many families, and the endoglucanases belonging to the glycoside hydrolase family 5 (GH5) have high similarity in both amino acid sequence and two strict conserved catalytic residues of glutamic acid (Yuan et al. 2019; Matsuyama et al. 1999). The two residues are considered as catalytic proton donors and active site nucleophiles, respectively. They can maintain the structure of the substrate isocarbon of the enzyme (Valérie et al. 1995). Cellulase is widely used in many fields, such as biofuel production, papermaking, textiles, food processing, brewing, and extraction of active ingredients of traditional Chinese medicine (Garg et al. 2016; Chia et al. 2016; Samkelo et al. 2020). Endocellulase has attracted attention because of its catalytic efficiency. So far, although various cellulase has been isolated from bacteria, fungi (Okada 1976), plants and higher animals, thermostable cellulase with excellent properties still needs to be discovered (Morteza et al. 2020; Zheng et al. 2018).

Ferula asafoetida is a rare medicinal plant resource distributed in Xinjiang in China. The distribution area of Ferula asafoetida in Shihezi on the southern edge of Junggar Basin experiences much dramatic temperature changes (e.g. long time sunshine, large difference of daily temperature) and high content of salt-alkali. Therefore, microbes and enzymes in the soils of this area are characteristic of salt alkali resistance and high thermal stability. Hence, the soils here are a good sample for screening new enzymes 
with industrial application potential. However, most of the microorganisms in the environment cannot be cultured with the existing techniques or be used for biotechnology or basic research (Amann et al. 1995; Schmitz et al. 2004). For example, only $1 \%$ or even less of prokaryotes in the soils are readily cultivatable (Griffiths et al. 1996). Metagenomic libraries containing DNA extracted directly from environmental samples provide genomic sequences, and phylogenetic and functional information (Jo et al. 2002). Thus, metagenomics, the genomic analysis of collective genomes in an assemblage of organisms, is suitable for screening new functional biocatalysts and molecules with industrial application potential from soils (Handelsman et al. 2004). Many new enzymes have been discovered by using metagenomics, such as lipases (Tirawongsaroj et al. 2008; Bayer et al. 2009), amylases (Yun et al. 2004), and cellulase (Nimchua et al. 2012; Ko et al. 2013; Amitha et al. 2013). To our knowledge, no study has reported any highly thermostable cellulase that is found through metagenomic screening from the soils of Ferula asafoetida distribution area.

Burning fossil fuels can cause environmental pollution (Bao et al. 2011). Cellulose is the most abundant component of lignocellulose in the biosphere, and the cheapest renewable and natural organic substance (Liu et al. 2011). Cellulosic ethanol is the best alternative to fossil fuels (Raj et al. 2018; Costa et al. 2018). However, many intermolecular, intramolecular hydrogen bonds and other intermolecular interactions result in the long-lasting chain conformation and tight chain filling of cellulose, which cannot be dissolved by ordinary solvents (Medronho et al. 2012). Moreover, the hydrolysis of cellulose by chemical methods to produce cellulosic ethanol is complicated and expensive (Salinas et al. 2011). The utilization of lignocellulosic biomass lacks effective low-cost means (Lynd et al. 2002).

Water hyacinth (Eichhornia crassipes) has abundant utilizable lignocellulosic biomass (Ismail et al. 1995). It can tolerate seasonal changes in flow rate, water level, $\mathrm{pH}$, nutrient availability, temperature, and toxic substances (Asrofi et al. 2018; Sumrith and Dangtungee 2019). Water hyacinth can multiply quickly at suitable temperature (between 10 and $35^{\circ} \mathrm{C}$ ) in a nutrition balanced environment (Mayo and Hanai 2017). The infestation of water hyacinth affects water transport and ecological balance, and causes secondary pollution of water bodies. These limitations are great challenges to the ecosystem. To solve these problems and make reasonable use of water hyacinth resources, some researchers have studied enzymatic degradation of water hyacinth. The reactions of $170 \mathrm{U} / \mathrm{g}$ cellulase from Trichoderma reesei with alkali-treated water hyacinth for $36 \mathrm{~h}$ (Ganguly et al. 2013), $30 \mathrm{FPU} / \mathrm{g}$ cellulase from Aspergillus fumigatus with acid-treated water hyacinth for $24 \mathrm{~h}$ (Das et al. 2013, 2016), and $10 \mathrm{FPU} / \mathrm{g}$ cellulase from T. atroviride with acid-treated water hyacinth for $70 \mathrm{~h}$ (Rajesh et al., 2014) lead to the maximum sugar yields of $299.13,425.6$ and $380.97 \mathrm{mg} / \mathrm{g}$ respectively. In this work, after $121.25 \mathrm{U} / \mathrm{g}$ Cel1029 (the enzyme loading of $1 \mathrm{~g}$ of water hyacinth is $121.25 \mathrm{U}$ ) reacts with acid-treated water hyacinth for $22 \mathrm{~h}$, the reducing sugar yield is $430.39 \mathrm{mg} / \mathrm{g}$ (sugar yield per gram of water hyacinth).

We metagenomically screened a novel type of cellulase through from the soils of Ferula asafoetida distribution area. The cellulase shows excellent thermal stability, tolerance against metal ions, organic solvents, and salt solutions, and high ability of degrading water hyacinth, which together prove its great potential for industrial application. 


\section{Materials And Methods}

\section{Strains, Materials, and Chemicals}

Escherichia coli BL21 (DE3) and E. coli DH5a (both from TSINGKE Biological Technology, Guangzhou, China) were used as the expression host and cloning host, respectively. The pET-32a (+) (Novagen) was used for protein expression. T4 DNA Ligases, restriction endonucleases and pUC118/BamHI (BAP) were purchased from TaKaRa (Dalian, China). DNA extraction kit, plasmid extraction kit and His-tag protein purification kit (Novagen) were provided by OMEGA (San Diego, CA, USA). Ampicillin (Amp), 5-Bromo-4chloro-3-indolyl- $\beta$-D-galactopyranoside (X-Gal), and isopropyl- $\beta$-D-thiogalactopyranoside (IPTG) were bought from Sigma. All other chemicals and reagents were produced by RUISHU Biological Technology (Guangzhou, China) unless otherwise stated. Water hyacinth was gathered locally. Molecular biology reagents from TaKaRa were used according to the manufacturer's instructions.

\section{Preparation of Water Hyacinth Biomass (WHB)}

Water hyacinth was collected from the lake of Guangdong Pharmaceutical University. Then the water hyacinth was chopped, dried at $105^{\circ} \mathrm{C}$, and finally ground into 0.1-1 mm powder (Amriani et al. 2016). A certain amount of WHB was added with dilute $\mathrm{H}_{2} \mathrm{SO}_{4}(2 \%)$ at the ratio of 1:10 (g/ml) under soaking for 1 $h$ at $40^{\circ} \mathrm{C}$. Then the dilute $\mathrm{H}_{2} \mathrm{SO}_{4}$ was drained, and $\mathrm{WHB}$ was washed to neutralize the $\mathrm{pH}$ with distilled water.

\section{DNA Extraction, Metagenomic Library Construction, and Cellulase Gene Screening}

A soil sample was collected from the wild Ferula asafoetida distribution area in Shihezi on the southern edge of Junggar Basin in Xinjiang. The sample was taken from 5-10 cm under the surface, sealed in a sterile bag, and preserved at $-20^{\circ} \mathrm{C}$ until DNA extraction. Total genomic DNA from the soil sample was extracted according to a reported method (Zhou et al. 1996). The amount of the DNA extraction buffer was increased from 2.7 to $3.5 \mathrm{~mL} / \mathrm{g}$, and the time of vortex shocking was prolonged from 30 to $45 \mathrm{~min}$. Genomic DNA was partially digested with EcoR I/Pst I/BamHI/Sau3A I. After determination of the optimal endonuclease, the enzyme digestion time of the soil DNA was optimized.

The DNA fragments obtained by the above method were purified using the OMEGA gel extraction kit. Then the purified DNA fragments were ligated with a pUC118/ BamHI vector overnight at $16^{\circ} \mathrm{C}$ for $12 \mathrm{~h}$ with T4 DNA ligase. This recombinant plasmid was converted into E. coli DH5a and cultivated in a solid medium containing $50 \mu \mathrm{g} / \mathrm{mL}$ Amp, $20 \mu \mathrm{g} / \mathrm{mL}$ IPTG, and X-Gal $(50 \mu \mathrm{g} / \mathrm{mL})$ at $37^{\circ} \mathrm{C}$ overnight.

The white colonies were expanded and cultured at $37^{\circ} \mathrm{C}$ and $220 \mathrm{rpm}$ for $14 \mathrm{~h}$. White colonies were randomly picked for the cellulase screening culture $(5 \mathrm{mg} / \mathrm{ml} \mathrm{CMC}, 50 \mu \mathrm{g} / \mathrm{mL} \mathrm{Amp})$ at $37^{\circ} \mathrm{C}$ for $24 \mathrm{~h}$. Then the hydrolysis circle of $\mathrm{CMC}$ was observed by Congo red staining. Firstly, $15 \mathrm{~mL}$ of a Congo red dyeing solution $(1 \mathrm{mg} / \mathrm{mL})$ was added for $1 \mathrm{~h}$ of dyeing, and after the waste liquid was discarded, and 15 $\mathrm{mL}$ of $\mathrm{NaCl}(1 \mathrm{~mol} / \mathrm{L})$ was added for $1 \mathrm{~h}$ of decolorization. An obvious hydrolysis circle demonstrating a 
potential for cellulase production was identified, as shown on the plates of solid CMC stained with Congo red $(1 \mathrm{mg} / \mathrm{mL})$. Colonies were purified by repeated streaking. Finally, the DNA of positive colonies was sequenced by TSINGKE Biological Technology (Guangzhou, China) and analyzed using bioinformatics programs, such as ORFfinder, BLAST and MEGA-X.

\section{Construction of Recombinant Plasmid and Transformation}

During PCR amplification, pUC118-cel1029 plasmid as the template, and cel1029-F and cel1029-R as primers were used. The amplified product and vector, pET-32a (+), was digested with BamHI and Hind III, and then linked by T4 DNA Ligase. Finally, the constructed vector, pET32a-cel1029, was transferred into E.coli BL21 (DE3). PCR primers for cel1029 amplification were as follows: cel1029-F, 5'CGGGATCCATGGGATCCGAACATCATCATCATCATC-3'; cel1029-R, 5'-CCAAGCTTTGCGCCC TTTTCCTTGTCGTTCA-3' (the BamHI and Hind III restriction sites were italicized). The PCR process was as follows: denaturation $2 \mathrm{~min}$ at $98^{\circ} \mathrm{C} ; 30$ cycles of $10 \mathrm{sec}$ at $98^{\circ} \mathrm{C}, 5 \mathrm{sec}$ at $64^{\circ} \mathrm{C}$, and $5 \mathrm{sec}$ at $72^{\circ} \mathrm{C}$; elongation for $8 \mathrm{~min}$ at $72^{\circ} \mathrm{C}$. The expression vector pET-32a (+) was digested using BamHI and Hind III at $37^{\circ} \mathrm{C}$ for $20 \mathrm{~min}$ and then ligated to the PCR products, which were treated with the same restriction endonuclease. The double-digested pET-32a (+) and the PCR products were ligated by TaKaRa T4 DNA Ligase at $16^{\circ} \mathrm{C}$ for $14 \mathrm{~h}$. This recombinant plasmid was transformed into E. coliBL21 (DE3) by a heat shock method.

\section{Expression, Protein Purification, and Electrophoresis}

The protein was expressed by growing the $E$. coli BL21(DE3) cells in an LB medium ( $50 \mu \mathrm{g} / \mathrm{mL}$, Amp). For purification of Cel1029 expressed by E. coli, the sediment was collected by centrifugation at $8000 \mathrm{rpm}$ and $4^{\circ} \mathrm{C}$ for 10 minutes. The sediment was washed with sterile water twice and broken using an ultrasonicator with an amplitude set at $30 \mathrm{~W}$ for 15 minutes. Recombinant cellulase Cel1029 was purified using the His-tag protein purification kit. The molecular weight of denatured protein was determined by SDS-PAGE. The molecular weight of the expressed protein was determined based on the protein markers (TaKaRa) as the standards. According to the predicted molecular weight of protein and its relationship with different concentrations of polyacrylamide gel, separation and concentration gels with the contents of $12 \%$ and $5 \%$ respectively were selected. The protein was stained with Coomassie brilliant blue G-250 for 10-12 $\mathrm{h}$, and then decolorized with eluent. For the CMC zymogram analysis, $2.75 \mathrm{ml}$ of a $1 \% \mathrm{CMC}$ solution was added into $12 \%$ separation gel. Then $5 \%$ concentrated gel was prepared, and the purified Cel1029 was loaded. After electrophoresis, the Cel1029 was fixed with glacial acetic acid for $1 \mathrm{~min}$, then reacted for $3 \mathrm{~h}$, dyed with a $1 \mathrm{mg} / \mathrm{ml}$ Congo red solution for $1 \mathrm{~h}$, and finally decolorized with $1 \mathrm{~mol} / \mathrm{L} \mathrm{NaCl}$ for $1 \mathrm{~h}$.

\section{Cellulase Activity Assay}

Cellulase activity was measured using $\mathrm{CMC}$ as the substrate. Cellulase hydrolyzed $\mathrm{CMC}$ into reducing sugar. The absorption peak of the reducing sugar was $540 \mathrm{~nm}$ after oxidation with dinitrosalisic acid (DNS) (Miller et al. 1959) in a boiling water bath. The absorption was linearly related with the content of reducing sugar. A standard curve was drawn using glucose concentration as the abscissa $(X)$ axis, and 
$A_{540}$ as the ordinate $(Y)$ axis. Reducing sugar content can be detected from the standard curve after the $A_{540}$ of the solution was measured. One unit was defined as the amount of enzyme that released $1 \mu \mathrm{mol}$ of reducing sugar per minute under the optimal conditions (Kang et al. 2007). All assays were performed in triplicate.

\section{Evaluation of Enzymatic Properties}

Cellulase activity was determined using $1 \%(\mathrm{w} / \mathrm{v}) \mathrm{CMC}$ as the substrate, as previously mentioned. At $50^{\circ} \mathrm{C}$, the enzyme activity was measured within $\mathrm{pH} 2-10$. Into $90 \mu \mathrm{L}$ of $1 \%(\mathrm{w} / \mathrm{v}) \mathrm{CMC}$ prepared with the $40 \mathrm{mM}$ BR buffer of different pHs, $10 \mu \mathrm{L}$ of purified enzyme solution was added for 30 min of reaction. Then $150 \mu \mathrm{L}$ of the DNS solution was added to react in boiling water for $10 \mathrm{~min}$, and the supernatant was collected to determine the $A_{540}$ and thereby the optimal $\mathrm{pH}$. The optimal temperature was investigated from 4 to $80^{\circ} \mathrm{C}$ at the optimal $\mathrm{pH}$. In brief, $2 \mathrm{~mL}$ of a crude enzyme solution was prepared with BR buffer solution of different $\mathrm{pHs}$, and stored at $4^{\circ} \mathrm{C}$ for $24 \mathrm{~h}$. Then $10 \mu \mathrm{L}$ of the crude enzyme solution was taken every $2 \mathrm{~h}$, and the residual enzyme activity was determined under the optimum temperature and $\mathrm{pH}$. The maximum enzyme activity was set as $100 \%$. The purified enzyme solution was placed at different temperatures $\left(4-80^{\circ} \mathrm{C}\right)$ for $24 \mathrm{~h}$, and sampled every $2 \mathrm{~h}$ for measurement of residual enzyme activity at the optimum temperature and $\mathrm{pH}$ according to the method above.

The effects of various metal ions $\left(\mathrm{K}^{+}, \mathrm{Na}^{+}, \mathrm{Fe}^{2+}, \mathrm{Mg}^{2+}, \mathrm{Mn}^{2+}, \mathrm{Ca}^{2+}, \mathrm{Cu}^{2+}, \mathrm{Zn}^{2+}, \mathrm{Ni}^{2+}\right.$, and $\left.\mathrm{Co}^{2+}\right)$ and chemicals (SDS, EDTA, urea, imidazole, methanol, ethanol, isopropanol, DMSO and Triton X-100) on Cel1029 activity were investigated by preincubating the enzyme with the reagents for $20 \mathrm{~min}$ at the optimum temperature and $\mathrm{pH}$. The enzyme activity without any reagent was set as $100 \% \mathrm{NaCl}$ was used to study the salt tolerance of the recombinant enzyme. The activity of the enzyme was determined in the optimal $\mathrm{pH}$ buffer with a 0 to $3 \mathrm{mM}$ salt solution at the optimal temperature and $\mathrm{pH}$. The enzyme without adding agent was used as a control.

$\mathrm{CMC}$ solutions in concentrations from 0.0 to $5.0 \mathrm{mg} / \mathrm{mL}$ were prepared with the buffer solution of the optimal pH. Then $90 \mu \mathrm{L}$ of the $\mathrm{CMC}$ solution at each concentration was added with $10 \mu \mathrm{L}$ of the 0.649 $\mathrm{mg} / \mathrm{ml}$ enzyme solution, and reacted for 30 minutes under the optimal temperature. After that, the reaction solution was taken out and added with $150 \mu \mathrm{L}$ of the DNS solution for 10 min of reaction in boiling water, followed by measurement of $A_{540}$. The absorbance at $0.0 \mathrm{mM}$ was taken as a negative control, and the concentration of glucose was determined. According to the substrate concentration [S] and the measured initial reaction rate $\mathrm{V}$, The Linear Weaver Burk double reciprocal plot $\left(\mathrm{V}=\mathrm{V}_{\max }[\mathrm{S}] /\left(\mathrm{K}_{\mathrm{m}}+\right.\right.$ [S] ) was plotted for $1 / V$, and the enzymatic kinetic parameters $K_{m}$ and $V_{\max }$ of cellulase were calculated.

\section{Enzymatic Hydrolysis of WHB}

The optimal conditions were tested with WHB. The water hyacinth contained high amounts of cellulose that was converted to a reducing sugar by cellulase. First, single-factor analysis was used to study the WHB degradation by changing the $\mathrm{pH}$, temperature, enzyme dosage, and enzymatic hydrolysis time. Then, an $\mathrm{L} 9\left(3^{4}\right)$ orthogonal design (Table 1 ) was used to determine an optimal degradation combination. 
The reaction mixtures contained the WHB $(0.2 \mathrm{~g})$, Britton-Robinson buffer $(40 \mathrm{mM})$, and cellulase in a 20$\mathrm{mL}$ system at $200 \mathrm{rpm}$. Enzymatic extraction of the WHB was determined using spectrophotometry. The supernatant was centrifuged to measure the absorbance at $540 \mathrm{~nm}$. The same amount of an inactivated enzyme solution was used as a negative control. All reactions were performed in triplicate.

Table 1

Orthogonal tests with three levels of each factor from low to high $(1,2$ and 3$)$.

\begin{tabular}{|llll|}
\hline Factor/Level & $\mathbf{1}$ & $\mathbf{2}$ & $\mathbf{3}$ \\
\hline A-Temperature $/{ }^{\circ} \mathrm{C}$ & 45 & 50 & 55 \\
B-Enzyme amount $/ \mathrm{ml}$ & 2 & 4 & 6 \\
C-pH & 4.0 & 5.0 & 6.0 \\
D-Time/h & 20 & 22 & 24 \\
\hline
\end{tabular}

\section{Nucleotide Sequence Accession Number}

This nucleotide sequence was declared to the GenBank at the registration number of MK051001.

\section{Results}

\section{Screening for Cellulase Using the Soil Metagenomic Library}

Metagenomic strategies are applied to isolate and identify novel enzymes with new catalytic or secondary metabolites from different environmental samples (Tang et al. 2018; Fan et al. 2017). The method of carboxymethyl cellulose sodium (CMC)-Congo red staining (Teather and Wood 1982) is often used to screen active clones of endoglucanase. In this study, we screened 7, 200 positive clones from a metagenomic library, which was built by extracting the total DNA from soil microbes. Results showed the optimum endonuclease was $\mathrm{BamHI}$ and the optimum time was $80 \mathrm{~min}$. The average fragment size of the total DNA was about 2-2.5 kb. Cellulases were screened from the metagenomic library by Congo red staining, and one putative cellulase clone was visually identifoed by a transparent hydrolytic circle with a diameter of $1.25 \mathrm{~cm}$ that appeared on the Congo red plate (Fig. 1).

The clone was sequenced and analyzed with ORFfinder of the National Center for Biotechnology Information (NCBI), which showed the full-length 1029 bp fragment contained a cellulase gene named cel1029. The cel1029 had an open reading frame of $927 \mathrm{bp}$ and encoded a $34.21 \mathrm{kDa}$ protein consisting of 309 amino acids. Conserved domain analysis revealed that $\mathrm{Ce} / 1029$ had a domain belonging to GH5 (312-1013 residues). Through multiple sequence alignments and protein BLAST search by BioEdiet, ESPript 3.0 and NCBI, Cel1029 was found to be similar with endo-1,4-D-glucanase (62.81\%, NCBI accession: P07103.2), endo-1,4-D-glucanase (48.48\%, P15704.1), endo-1,4-D-glucanase (41.06\%, P10475.1), endo-1,4-D-glucanase (41.06\%, P07983.2), endo-1,4-D-glucanase (40.07\%, P23549.1), endo1,4-D-glucanase (42.57\%, P06565.1), endo-1,4-D-glucanase (48.07\%, 085465.1), and endo-1,4-D- 
glucanase (48.07\%, P06566.1) (Fig. 2). These sequences were strictly conserved at two catalytic residue sites - Glu176 and Glu264. The two residues served as catalytic proton donors and active site nucleophiles, respectively, and can maintain the structure of the substrate isocarbon for the enzyme. A phylogenetic tree was constructed by neighbor joining to verify the evolutionary relationship of Ce/1029 with 14 known endoglucanases. Results show that Cel1029 is closely related to three endocellulases from Bacillus sp. (Fig. 3). Multiple sequence alignments and phylogenetic tree analysis indicate that Cel1029 is an endo-1,4-D-glucanase (EC3.2.1.4) belonging to GH5.

\section{Cloning and Overexpression of Cellulase Gene in E. coli and Purification of Recombinant Protein}

PCR was conducted by using plasmids pUC118-cel1029 as the template and cel1029-F and cel1029-R as primers. The amplified fragment length was consistent with the predicted target DNA fragment length of 1029 bp. pET32a-cel1029 was identified by the verified enzyme digestion (Fig. 4) and the confirmed DNA sequencing. Cel1029 was expressed in E. coli BL21 (DE3). According to the optimal induction

temperature $\left(30^{\circ} \mathrm{C}\right)$ and time $(14 \mathrm{~h})$, the optimal induction concentration of IPTG was $0.9 \mathrm{mM}$. Expression strain was induced by IPTG and then broken by ultrasound. The crude enzyme was purified and then analyzed by SDS-polyacrylamide gel electrophoresis (SDS-PAGE) (Cheeseman et al. 2001). The enzyme was purified by about 9 -fold, with a specific activity of $883 \pm 25 \mathrm{U} / \mathrm{mg}$. Figure 5 shows the approximate target band $(37.8 \mathrm{kDa})$, including the theoretically calculated the cellulose enzyme molecular weight $(34.21 \mathrm{kDa})$ and protein molecular tag weight $(3.63 \mathrm{kDa})$. The recombinant protein was highly soluble expressed in E.coli, which is also the premise and basis for industrial application. The results of CMC zymogram analysis show a translucent zone (Fig. 6) that indicates CMCase activity.

M, DL45, 00 DNA Marker; Lane 1, Recombinant plasmid; Lane 2, Recombinant plasmid digestion by BamHI and Hind III. The target band is located between 800 and $1200 \mathrm{bp}$

\section{Characterization of Recombinant Cel1029}

According to the relationship between the concentration of the standard glucose solution and the absorbance at $540 \mathrm{~nm}$, we obtained the regression equation of the standard curve $(\mathrm{Y}=0.7609 \cdot \mathrm{X}+$ $\left.0.00916, \mathrm{R}^{2}=0.998\right)$. Cel1029 was active over a wide $\mathrm{pH}$ range, maintaining $40 \%$ of its optimum activity at pH 2.0 and stable between $\mathrm{pH} 5.0$ to 7.0 (Fig. 7A). The optimal reaction temperature of $\mathrm{Cel} 1029$ at the optimal reaction $\mathrm{pH}$ was measured with $\mathrm{CMC}$ as the substrate (Fig. 7B). The maximum enzyme activity was defined as $100 \%$. Cel1029 retained $85.3 \%$ of the maximum activity at $4^{\circ} \mathrm{C}$ and $68.5 \%$ at $80^{\circ} \mathrm{C}$.

Maximum activity occurred at $55^{\circ} \mathrm{C}$, and more than $50 \%$ activity was retained at $4-80^{\circ} \mathrm{C}$, indicating that Cel1029 has high adaptability at a wide temperature range. More than $86 \%$ of maximum activity was retained at $4-60^{\circ} \mathrm{C}$ after $24 \mathrm{~h}$ (Fig. 7D), indicating that Cel1029 has excellent thermal stability. Cellulase activity was obviously enhanced by the addition of $\mathrm{Co}^{2+}$ and slightly inhibited by $\mathrm{Ni}^{2+}$ (Fig. 8). The influence of $\mathrm{Co}^{2+}$ concentration on Cel1029 was further studied, and results showed $10 \mathrm{mM} \mathrm{Co}^{2+}$ promoted enzyme activity to $156.18 \%$. 
Cel1029 was stable in some common organic and nonionic solvents, as more than $50 \%$ activity was retained in all tested solvents at different concentrations (Fig. 9). Especially, the residual enzyme activity of Cel1029 was $95.3 \%$ when the SDS concentration was $1 \mathrm{mM}$, and still reached about $70 \%$ and $50 \%$ when the SDS concentration increased to 10 and $100 \mathrm{mM}$, respectively. Cel1029 was highly resistant against methanol and isopropanol, and its activity increased in the $1 \%(\mathrm{v} / \mathrm{v})$ concentration.

$\mathrm{NaCl}(0$ to $3 \mathrm{M}$ ) was used to study the salt tolerance of the recombinant enzyme under the optimal temperature and $\mathrm{pH}$. The enzyme activity was maintained above $80 \%$ when the salt concentration was 3.0 M (Fig. 10).

Determining $\mathrm{K}_{\mathrm{m}}$, the most important characteristic constant of enzymes, is an important method to study enzyme kinetics and reflects the magnitude of affinity between an enzyme and the substrate. In the past, Michaelis-Menten parameters were used to test the $K_{m}$ and $V_{m a x}$ of cellulase (King et al. 2009). Then Lineweaver and Burk used the equation derived from the Michaelis-Menten equation to determine $\mathrm{K}_{\mathrm{m}}$ and $\mathrm{V}_{\text {max }}$ to be $0.535 \mathrm{mM}$ and $1.588 \mathrm{mM} / \mathrm{min}$, respectively.

\section{Enzymatic Hydrolysis of Water Hyacinth}

The content of reducing sugar was $17.3 \pm 0.7 \mathrm{mg} / \mathrm{g}$ in the negative control, and was $59 \pm 3.8 \mathrm{mg} / \mathrm{g}$ in WHB before elution, indicating a part of reducing sugar was lost during the pretreatment of water hyacinth with $\mathrm{H}_{2} \mathrm{SO}_{4}$. The optimal conditions of enzymatic hydrolysis to WHB were studied by spectrophotometry (Fig. 11). The sugar yield (sugar production/WHB quality, mg/g) reached $331.99 \mathrm{mg} / \mathrm{g}$ at pH 5 (Fig. 11A) and decreased almost linearly with the increasing pH. The sugar yield was only 213.65 $\mathrm{mg} / \mathrm{g}$ at $\mathrm{pH} 8$, and minimized to $230.92 \mathrm{mg} / \mathrm{g}$ at $35^{\circ} \mathrm{C}$. The sugar yield also increased with temperature rise and maximized to $383.57 \mathrm{mg} / \mathrm{g}$ at $50^{\circ} \mathrm{C}$ (Fig. 11B). However, the sugar yield decreased when the temperature exceeded $50^{\circ} \mathrm{C}$. Therefore, the sugar yield of WHB was highest at $50^{\circ} \mathrm{C}$. The maximum sugar yield reached $356.30 \mathrm{mg} / \mathrm{g}$ with $2 \mathrm{~mL}$ of enzyme (24.25U, Fig. 11C). Figure 11D shows the effect of enzymatic hydrolysis time on the sugar yield. The sugar yield of WHB maximized to $395.19 \mathrm{mg} / \mathrm{g}$ when the enzymatic hydrolysis time was 24 hours. Table 2 shows the results of the orthogonal test. The primary factor affecting the sugar yield of WHB is enzymatic hydrolysis time, followed by the secondary factors, including $\mathrm{pH}$, addition amount and temperature. The optimal conditions for a peak sugar yield (430.39 mg/g) of WHB are as follows: $50^{\circ} \mathrm{C}, 4 \mathrm{~mL}$ of enzyme, $\mathrm{pH} 6.0$, and 22 hours of enzymatic hydrolysis. 
Table 2

Orthogonal test results and analysis. $\mathrm{K}_{1}, \mathrm{~K}_{2}$ and $\mathrm{K}_{3}$ represented the average value of the corresponding factor in each column in three experiments at level 1, 2 and 3 . R represented the difference between the maximum $\mathrm{K}$ value and the minimum $\mathrm{K}$ value in each column

\begin{tabular}{|llllll|}
\hline Test No. & A-Temperature/ ${ }^{\circ} \mathrm{C}$ & B-Enzyme amount/ml & C-pH & D-Time/h & Sugar yieled/mg/g \\
\hline 1 & 1 & 1 & 1 & 1 & 278.02 \\
\hline 2 & 1 & 2 & 2 & 2 & 430.39 \\
\hline 4 & 1 & 3 & 3 & 3 & 212.67 \\
\hline 5 & 2 & 1 & 2 & 3 & 335.01 \\
\hline 6 & 2 & 2 & 3 & 1 & 327.28 \\
\hline 7 & 3 & 3 & 1 & 2 & 312.72 \\
\hline 8 & 3 & 1 & 3 & 2 & 365.52 \\
\hline 9 & 3 & 2 & 1 & 3 & 285.90 \\
\hline$K_{1}$ & 308.36 & 3 & 2 & 1 & 362.00 \\
\hline$K_{2}$ & 337.81 & 326.19 & 266.70 & 321.10 & \\
\hline$K_{3}$ & 323.67 & 346.52 & 375.80 & 369.54 & \\
\hline$R$ & 29.45 & 297.13 & 301.82 & 279.19 & \\
\hline
\end{tabular}

\section{Discussion}

Metagenomic strategies have been applied to isolate and identify novel enzymes with new catalytic or secondary metabolites from different environmental samples. A metagenomic library was built successfully using DNA extracted from crop residues of red rice with castor bean cake and a new phytase was screened (Farias et al. 2018). A novel $\beta$-glucosidase gene $b g / 2238$ was screened from the macrogenomic library by functional screening (Tang et al. 2018). A novel gene (aii810) encoding an $\mathrm{N}$ acylhomoserine lactonase was isolated from the Mao-tofu metagenome for the first time (Fan et al. 2017). CMC-Congo red staining (Teather and Wood 1982) is often used to screen active clones of endoglucanase. The main limitation of metagenomic libraries is the need of suitable hosts to promote heterologous expression (Carlos et al. 2016). This limitation is mainly attributed to the difficulties in identifying regulatory elements and the existence of different codons (Wang et al. 2016). In an arid agricultural system, the dominant flora include spore-forming strains of Bacillus and Paenibacillus, while Streptomyces is more abundant in natural desert systems (Schrempf 2013). The codons of the actinomycete shine Dalgarno promoter region are different from those of $E$. coli, so heterologous 
expression is difficult for the cellulase mainly from Actinomycetes screened in natural desert systems. In this study, the cellulase gene cel1029 was successfully expressed in E.coli. Direct extraction of soil samples was adopted, and the amount of DNA extraction buffer and the time of vortex shock were increased to reduce microbial adsorption by soils and enhance the degree of DNA dissolution. In addition, a Congo red screening medium was used here, which can show a transparent hydrolysis circle, increase the recognition and reduce the probability of missing positive clones from the metagenomic library.

Cel1029 has high adaptability at wide ranges of temperature and $\mathrm{pH}$, and excellent thermal and $\mathrm{pH}$ stability. Several reports on thermostable cellulase show similar catalytic activity at high temperature. The optimal temperature of Cel1029 is slightly higher than that of Lp-egl-1 from Lyrodus pedicellatus (Hiroshi et al. 2008) and PersiCel 1 from camel rumen metagenome (Morteza et al. 2020). On the basis of hot activity, Cel1029 outperforms PersiCel2 with about $10 \%$ activity at $80^{\circ} \mathrm{C}$ (Morteza et al. 2020), but is worse than $R 63$ from Thermoanaerobacterium $s p$ with about $80 \%$ activity at $75^{\circ} \mathrm{C}$, (Harnvoravongchai et al. 2020) and $P W 2$ from Bacillus sp. with $100 \%$ activity at $80^{\circ} \mathrm{C}$ (Divyanshi et al. 2019). The residual activity at $70^{\circ} \mathrm{C}$ is $48.1 \%$ after incubation for $24 \mathrm{~h}$, which is better than that of $\mathrm{MaCel}$ (Tong et al. 2020). In terms of $\mathrm{pH}$ adaptability, the optimum $\mathrm{pH}$ of PersiCel1 with good pH adaptability is 5 (Morteza et al. 2020), and the relative enzyme activity is about $40 \%$ at pH 4 and pH 10. The optimum pH of ZFYN184 from soil metagenomic library is 4 (Chai et al. 2020), and the relative enzyme activity is lower than $10 \%$ at $\mathrm{pH} 3$ and $\mathrm{pH}$ 6. The optimum $\mathrm{pH}$ of $\mathrm{Ce} / 1029$ is 6 , and the relative enzyme activity is slightly higher than $40 \%$ at $\mathrm{pH} 2$, and above $45 \%$ at $\mathrm{pH} 10$. In conclusion, Cel1029 has obvious advantages in temperature and $\mathrm{pH}$ adaptability.

Activity of $\mathrm{Ce} / 1029$ is obviously enhanced by the addition of $\mathrm{Co}^{2+}$ and slightly inhibited by $\mathrm{Ni}^{2+}$. Similar phenomena have been reported, in which $0.5 \mathrm{mM} \mathrm{Co}^{2+}$ double-increased the enzyme activity of $\mathrm{MaCel}$ (Tong et al. 2020) and $1 \mathrm{mM} \mathrm{Co}^{2+}$ promoted the activity of AgCMCase (Kumar et al. 2015). The results suggest that $\mathrm{Ce} / 1029$ is resistant against most metal ions. The enzyme activity can be increased by adding appropriate metal ions in industrial production. To determine the usefulness of Ce/1029 in industrial applications, it is necessary to study the effects of organic and nonionic solvents on its activity and stability. Interestingly, when the SDS concentration increases to 10 and $100 \mathrm{mM}$, the residual enzyme activity is still about $70 \%$ and $50 \%$ respectively. $B C 1$, an alkalophilic cellulase from the symbiotic Bacillus subtilis, retains about $30 \%$ at the presence of $1 \%$ SDS (Dehghanikhah et al. 2020). GAC 16.2 from Acinetobacter junii reserves $66.1 \%$ activity with the presence of $5 \mathrm{mM}$ SDS (Sandipan et al. 2020). Cel1029 has obvious advantages in tolerance against SDS. On the one hand, SDS increases the surface negative charge of cellulase and the substrate, increasing the electrostatic repulsion between cellulase and the substrate. Finally, the binding ability between cellulase and the substrate and the hydrolysis ability of cellulase are decreased. On the other hand, the ineffective adsorption between cellulase and the substrate makes the enzyme irreversibly adsorbed on the substrate surface (Palonen et al. 2004), which results in the change of protein conformation, protein denaturation, and decrease of cellulase activity (Norde and Favier 1992). SDS is adsorbed onto the surface of the substrate through hydrogen bonding (Borjesson et al. 2007) and hydrophobic interaction, which significantly reduce the ineffective adsorption 
of the substrate and enzyme and enhances the cellulase activity in the liquid phase (Bálint et al. 2011). The relative activity of Cel1029 is still about $50 \%$ with the presence of $100 \mathrm{mM}$ SDS, indicating the negative charge of SDS has a weak effect on the binding degree of Cel1029 and the substrate, which may be affected by the charge properties of Cel1029. SDS may largely reduce the ineffective adsorption of Cel1029 onto the substrate. Cel1029 can well resist methanol and isopropanol, and its activity is increased at the concentration of $1 \%(\mathrm{v} / \mathrm{v})$. Similar performances have been reported. The activity of HSC7 from Bacillus sonorensis increases to $166 \%$ in the presence of methanol (Azadian et al. 2017). The activity of Est906 (Xiaolin et al. 2020) from paper mill waste water sediments is enhanced to $119.8 \%$ in the presence of isopropanol. These results suggest that adding appropriate organic or nonionic solvents into industrial production may strengthen the enzyme activity. Recombinant Cel1029 reserves above 80\% activity when the salt concentration is $3.0 \mathrm{M}$, and thus is more stable than $S R 22$ from Bacillus $s p$. strain (Santos et al. 2018), indicating that Cel1029 has high tolerance against salt solutions. The $\mathrm{K}_{\mathrm{m}}$ and $\mathrm{V}_{\max }$ of cellulase from Aspergillus fumigatus are $10.052 \mathrm{mM}$ and $1.38 \mathrm{mM} / \mathrm{min}$, respectively (Prabhpreet et al. 2020). NTU-05 from Salinivibrio $s p$. has $\mathrm{K}_{\mathrm{m}}$ of $3.03 \mathrm{mg} / \mathrm{ml}(12.5 \mathrm{mM})$ and $\mathrm{V}_{\max }$ of $0.14 \mathrm{mM} / \mathrm{min}$ when tested using CMC (Chungyi et al. 2009). The $\mathrm{K}_{\mathrm{m}}$ and $\mathrm{V}_{\max }$ of Cel1029 are $0.535 \mathrm{mM}$ and $1.588 \mathrm{mM} / \mathrm{min}$, respectively, suggesting that Cel1029 has higher affinity to $\mathrm{CMC}$ as the substrate.

Water hyacinth is rich in cellulose, which is hydrolyzed into cellobiose or glucose by enzymes such as cellulase. Cellulase can degrade cellulose into cellulosic ethanol, and then produce bio-fuels by microbial fermentation, which can optimize the use of WHB as a resource (Ma et al. 2010). In this study, the degradation of water hyacinth by cellulase Cel1029 was studied preliminarily. The reducing sugar yield of WHB through biotransformation of Cel1029 under optimal conditions is $84.36 \%$ of the theoretical maximum reducing sugar yield, which is about $510.2 \mathrm{mg} / \mathrm{g}$ (Klass et al. 1981; Nigam et al. 2002; Kumar et al. 2009). So far, it has not been reported that the cellulase degrades water hyacinth with such high efficiency.

\section{Conclusions}

A soil metagenomic library was constructed and a new cellulase gene, ce/1029, was cloned by using an activity-based functional method. Cel1029 was successfully expressed in the prokaryotic system to explore its stability, enzymatic properties, and ability to degrade water hyacinth. It showed high activity in a wide $\mathrm{pH}$ range, good thermostability, and excellent tolerance against organic solvents and salts. The recombinant enzyme was purified and characterized. The selected new cellulase was used to degrade and transform water hyacinth, and directly damaged the plant cell walls. Cellulase directly converted water hyacinth into glucose during the short test period, indicating a potential application of water hyacinth for use in energy production. We present new cellulase from the soils of Ferula asafoetida distribution area, enrich the source of cellulase, and make full use of cellulase. Meanwhile, this study provides a research basis for improving the utilization rate of cellulose-rich plants.

\section{Declarations}




\section{Funding}

This research has been funded by Natural Science Foundation of China (31400680), Science and Technology Plan Project of Guangzhou (201802030009), the Innovation and Strengthening School Project from Guangdong Pharmaceutical University (2016KTSCX067 and 2016SFKC_28), Science and Technology Plan Project of Guangdong Province (2017A010105011, 2014A020208134, 2014A020212602), and Education Project of Guangdong Province (2013KJCX0107).

\section{Acknowledgments}

The authors would like to thank Guangzhou Basic Clean Cosmetics Manufacturing Co. Ltd. for the financial support.

Compliance with ethical standards

\section{Conflicts of Interest}

Xiaoshen Zhao, Liyang Liu, Zujun Deng, Shan Liu, Jeonyun Yun, Xiong Xiao and He Li declare that they have no conflict of interest.

\section{Consent to participate}

(Not applicable)

\section{Consent for publication}

(Not applicable)

\section{Availability of data and material}

(Not applicable)

\section{Code availability}

(Not applicable)

\section{Authors' contributions}


Conceptualization, X.S.Z.; methodology, J.Y.; software, Z.J.D.; validation, X.S.Z., S.L. and J.Y.; formal analysis, X.S.Z.; investigation, Z.J.D.; resources, Z.J.D.; data curation, X.X.; writing-original draft preparation, X.S.Z.; writing-review and editing, L.Y.L.; visualization, X.X.; supervision, H.L.; project administration, H.L.; funding acquisition, S.L.. All authors have read and agreed to the published version of the manuscript.

\section{References}

1. Amann R I, Ludwig W, Schleifer KH (1995) Phylogenetic identification and in situ detection of individual microbial cells without cultivation. Microbiol Rev 59:143-169

2. Amitha PR, Christopher WS, Patrik D, Jane K, Helcio B, Masood H, Blake AS, Steven WS, Michael PT, Jean SVG (2013) Discovery of microorganisms and enzymes involved in high-solids decomposition of rice straw using metagenomic analyses. Plots One 8:2-10

3. Amriani F, Salim FA, Iskandinata I (2016) Physical and biophysical pretreatment of water hyacinth biomass for cellulase enzyme production. Che Biochem Eng Q 30:237-244

4. Asrofi M, Abral H, Putra YK, Kim HJ (2018) Effect of duration of sonication during gelatinization on properties of tapioca starch water hyacinth fiber biocomposite. Int J Biol Macromol 108:167-176

5. Azadian F, Badoei-Dalfard A, Namaki-Shoushtari A, Karami Z, Hassanshahian M (2017) Production and characterization of an acido-thermophilic, organic solvent stable cellulase from Bacillus sonorensis $\mathrm{HSC7}$ by conversion of lignocellulosic wastes.

Journal of Genetic Engineeringand Biotechnology 15(1):187-196

6. Bálint S, Mátyás S, Zoltán S, Perazzini R, Dienes D, Jakab E, Crestini C, Réczey K (2011) Mechanism of the positive effect of poly(ethylene glycol) addition in enzymatic hydrolysis of steam pretreated lignocelluloses. C R Biol 334(11):812-823

7. Bao L, Huang Q, Lei C, Jungang Z, Hong L (2011) Screening and characterization of a cellulase with endocellulase and exocellulase activity from yak rumen metagenome. J Mol Catal B-Enzym 73:104110

8. Bayer S, Ballschmiter M, Greiner-Stoeffele T (2009) Identification of a new lipolytic enzyme family and several novel nitrilases in metagenomic libraries. New Biotechnol 25(S):S72-S73

9. Borjesson J, Engqvist M, Sipos B, Tjerneld F (2007) Effect of poly(ethylene glycol) on enzymatic hydrolysis and adsorption of cellulase enzymes to pretreated lignocellulose. Enzyme Microb Technol 41(1-2):186-195

10. Carlos M, Bruna S, Betsy M, Rodrigo S, David JM (2016) A Metagenomic Advance for the Cloning and Characterization of a Cellulase from Red Rice Crop Residues. Molecules 21:831

11. Chai SM, Zhang XL, Jia ZY, Xu XF, Zhang YF, Wang FC, Feng ZY (2020) Identification and characterization of a novel bifunctional cellulase/hemicellulase from a soil metagenomic library. Appl Microbiol Biotechnol 104(17):7563-7572. 
12. Cheeseman, MT, Bates, PA, Crampton, JM (2001) Preliminary characterisation of esterase and platelet-activating factor (PAF)-acetylhydrolase activities from cat flea (Ctenocephalides felis) salivary glands. Insect Biochemistry and Molecular Biology 31:157-164

13. Chia K, Bao C, Yung L, Jiann HC, Chwen JS (2016) Production of Resveratrol by Piceid Deglycosylation Using Cellulase. Catalysts 6:32-42

14. Chungyi W, Yiru H, Changchai N, Helen C, Hsintang L, Wensheng T, Yuantay S (2009) Purification and characterization of a novel halostable cellulase from Salinivibrio $s p$ strain NTU-05. Enzyme Microb Tech, 44( 6-7):373-379

15. Costa S, Rugiero I, Uria CL (2018) Lignin degradation efficiency of chemical pre-treatments on banana rachis destined to bioethanol production. Biomolecules 8:141-156

16. Das A, Ghosh P, Paul T, Uma B, Ranjan P, Keshab C (2016) Mondal Production of bioethanol as useful biofuel through the bioconversion of water hyacinth (Eichhornia crassipes). Biotech 6:70

17. Das A, Paul T, Halder SK, Maity C, Das MPK, Pati BR, Mondal KC (2013) Study on regulation of growth andbiosynthesis of cellulolytic enzymes from newly isolated Aspergillus fumigatus ABK9. Polish J Microbiol 62:31-43

18. Dehghanikhah F, Shakarami J, Asoodeh A (2020) Purification and Biochemical Characterization of Alkalophilic Cellulase from the Symbiotic Bacillus subtilis BC1 of the Leopard moth Zeuzera pyrina (L.) (Lepidoptera; Cossidae). Curr Microbiol DOI:10.1007/s00284--020-01938-z

19. Divyanshi S, Parul S, Kamal D, Anuradha S (2019) Endoglucanase gene of M42 aminopeptidase/endoglucanase family from thermophilic Bacillus sp PW1 and PW2 isolated from Tattapani hot spring, Himachal Pradesh, India. Journal of Genetic Engineeringand Biotechnology 17(1):1-11

20. Fan XJ, Liang MJ, Wang L, Chen R, Li H, Liu XL (2017) Aii810, a novel cold-adapted NAcylhomoserine lactonase discovered in a metagenome, can strongly attenuate Pseudomonas aeruginosa virulence factors and biofilm formation. Front Microbiol 8:1950

21. Farias N, Isabela A, Carlos M (2018) New Bacterial Phytase through Metagenomic Prospection. Molecules 23(2):448

22. Ganguly A, Das S, Bhattacharya A, Dey A, Pradip KC (2013) Enzymatic hydrolysis of water hyacinth biomass for the production of ethanol: Optimization of driving parameters. Indian J Exp Biol 51:556566

23. Garg R, Srivastava R, Brahma V, Verma L, Karthikeyan S, Sahni G (2016) Biochemical and structural characterization of a novel halotolerant cellulase from soil metagenome. entific Reports 6:39634

24. Griffiths BS, Ritz K, Glover LA (1996) Broad-scale approaches to the determination of soil microbial community structure: application of the community DNA hybridization technique. Microbial Ecol $31: 269-280$

25. Handelsman J (2004) Metagenomics: application of genomics to uncultured microorganisms. Microbiol Mol Bio Rev 68:669-685 
26. Harnvoravongchai P, Singwisut R, Ounjai P, Amornrat A, Surang C (2020) Isolation and characterization of thermophilic cellulose and hemicellulose degrading bacterium, Thermoanaerobacterium sp R63 from tropical dry deciduous forest soil. Plos one 15(7):e0236518

27. Hiroshi T, Naoki N, Yoshihiko A, Kouichi N, Makoto, S (2008) Gene cloning of cellobiohydrolase II from the white rot fungus irpex lacteus MC-2 and Its expression in pichia pastoris. Biosci Biotech Bioch 72(12): 3142-3147

28. Ismail AM, Naby MA, Fattah AF (1995) Utilization of water hyacinth cellulose for production of cellobiase-rich preparation by Aspergillus niger. Microbios 83:191-8

29. Jo H, Mark L, David M, Christian R, Robert M (2002) Cloning the metagenome: Culture-independent access to thediversity and functions of the uncultivated microbial world. Method Microniol 33:241255

30. Kang HJ, Koichi U, Harumi F (2007) Improvement of the enzymatic activity of the hyperthermophilic cellulase from Pyrococcus horikoshii. Extremophiles 11:251-256

31. King A, Zoia L, Filpponen I (2009) In situ determination of lignin phenolics and wood solubility in imidazolium chlorides using (31)P NMR. J Agric Food Chem 57:8236-43

32. Klass DL, Ghosh S (1981) Methane production by anaerobic digestion of water hyacinth (Eichhornia crassipes). Fuel Chem 25:41

33. Ko KC, Lee JH, Han Y, Choi JH, Song JJ (2013) A novel multifunctional cellulolytic enzyme screened from metagenomic resources representing ruminal bacteria. Biochem Bioph Res Co 441:567-572

34. Kumar A, Singh LK, Ghosh S (2009) Bioconversion of lignocellulosic fraction of water-hyacinth (Eichhornia crassipes) hemicellulose acid hydrolysate to ethanol by Pichia stipites. Bioresour Technol 100:3293-3297

35. Kumar AK, Parikh, BS (2015) Cellulose-degrading enzymes from Aspergillus terreus D34 and enzymatic saccharification of mild-alkali and dilute-acid pretreated lignocellulosic biomass residues. Bioresour Bioprocess 2(1):1-13

36. Lin L, Liu X, Zhou Y, Guan L, He J, Huang W (2016) A novel pH-stable, endoglucanase $\ J q C e l 5 A \rrbracket$ isolatedfrom a salt-lake microorganism, Jonesia quinghaiensis. Electron J Biotechn 24:56-62

37. Liu D, Zhang R, Yang X, Hong SW, Da BX, Zhu T, Qi RS (2011) Thermostable cellulase production of Aspergillus fumigatus $Z 5$ under solid-state fermentation and its application in degradation of agricultural wastes. Int Biodeterior Biodegradation 65:717-725

38. Lynd LR, Weimer PJ, Van ZWH, Isak SP (2002) Microbial cellulose utilization: fundamentals and biotechnology. Microbio Mol Biol R 66:506-577

39. Ma FY, Yang N, Xu CY, Yu HB, Wu JG, Zhang XY (2010) Combination of biological pretreatment with mild acid pretreatment for enzymatic hydrolysis and ethanol production from water hyacinth. Bioresour Technol 101:9600-9604

40. Matsuyama H, Kawasaki K, Yumoto I, Shida O (1999) Microbacterium kitamiense sp nov a new polysaccharide-producing bacterium isolated from the waste-water of a sugar-beet factory. Int J Syst Bacteriol 49:1353-1357 
41. Mayo AW, Hanai EE (2017) Modeling phytoremediation of nitrogen-polluted water using water hyacinth (Eichhornia crassipes). Phys Chem Earth 100:170-180

42. Medronho B, Romano A, Maria G M, Lars S, Björn L (2012) Rationalizing cellulose (in)solubility: reviewing basic physicochemical aspects and role of hydrophobic interactions. Cellulose 19:581-587

43. Miller GL (1959) Use of dinitrosalicylic acid reagent for determination of reducing sugar. Anal Chem 31:426-8

44. Morteza M, Mehdi FS, Kaveh K, Shohreh A, Ghasem HS (2020) A novel thermostable cellulase cocktail enhances lignocellulosic bioconversion and biorefining in a broad range of $\mathrm{pH}$. Int J Biol Macromol 154:349-360

45. Morteza MA, Mehdi FSB, Kaveh KB, Shohreh AA, Ghasem H S A C (2020) A novel thermostable cellulase cocktail enhances lignocellulosic bioconversion and biorefining in a broad range of $\mathrm{pH}$. Int J Biol Macromol 154:349-360

46. Nigam JN (2002) Bioconversion of water-hyacinth (Eichhorniacrassipes) hemicellulose acid hydrolysate to motor fuel ethanolby xylose-fermenting yeast. J Biotechnol 97:107-116

47. Nimchua $T$, Thongaram $T$, Uengwetwanit $T$, Somchai $P$, Lily E (2012) Metagenomic analysis of novel lignocellulose-degrading enzymes from higher termite guts inhabiting microbes. J Microbio Biotechn 22:462-9

48. Norde W, Favier JP (1992) Structure of adsorbed and desorbed proteins. Colloids Surf 64(1):87-93 49. Okada G (1976) Enzymatic studies on a cellulase system of Trichoderma viride IV Purification and properties of a less-random type cellulase. Journal of biochemistry 80:913-22

50. Palonen H, Tjerneld F, Zacchi G, Tenkanen M (2004) Adsorption of Trichoderma reesei CBH I and EG II and their catalytic domains on steam pretreated softwood and isolated lignin.. J Biotechnol 107(1):65-72

51. Prabhpreet K, Monica S, Taggar AK (2020) Characterization of magnetic nanoparticle-immobilized cellulases for enzymatic saccharification of rice straw. Biomass Convers Bior pp:1-15

52. Raj K, Krishnan C (2018) High sugar yields from sugarcane (Saccharum officinarum) bagasse using low-temperature aqueous ammonia pretreatment and laccase-mediator assisted enzymatic hydrolysis. Ind Crops Prod 111:673-683

53. Rajesh D, Anil D, Sakshi (2014) Bioconversion of Water Hyacinth to Ethanol by Using Cellulase from Trichoderma atroviride AD-130. Adv Mat Res 3135:145-148

54. Salinas A, Vega M, María EL, Alejandro G, Rene C, Oriana S (2011) Cloning of novel cellulases from cellulolytic fungi: Heterologous expression of a family 5 glycoside hydrolase from Trametes versicolor in Pichia pastoris. Enzyme Microb Technol 49:485-491

55. Samkelo M, Shaunita HR, Willem HZ, Brett IP (2020) Enzymatic Hydrolysis of Softwood Derived Paper Sludge by an In Vitro Recombinant Cellulase Cocktail for the Production of Fermentable Sugars. Catalysts 10:775-792 
56. Sandipan B, Tushar KM, Raj NR (2020) Production, purification, and characterization of cellulase from Acinetobacter junii GAC 16.2, a novel cellulolytic gut isolate of Gryllotalpa africana , and its effects on cotton fiber and sawdust. Ann Microbiol 70(1):853-866

57. Santos YQD, Veras BOD, Jácomede FAF, Gorlach-Lira K, Elizeu ADS (2018) A new salt-tolerant thermostable cellulase from a marine Bacillus sp strain. J Microbiol Biothechn 28(7):1078-1085

58. Schmitz, A (2004) Metagenomics-the key to the uncultured microbes. Curr Opin Microbiol 7:492-498

59. Schrempf H (2013) Actinobacteria within soils: capacities for mutualism, symbiosis and pathogenesis. FEMS Microbiol Lett 342: 77-78

60. Sumrith N, Dangtungee R (2019) Mechanical properties of water hyacinth fiber reinforced bio-based epoxy composite. Fibers 4829:7-11

61. Tang LL, Wang XM, Wu XL, Huang Q, Li H (2018) Screening, cloning and characterization of a novel $\beta$-Glucosidase from soil metagenomic library. FoodSci 39:118-124

62. Teather RM, Wood PJ (1982) Use of Congo red-polysaccharide interactions in enumeration and characterization of cellulolytic bacteria from the bovine rumen. Appl Environ Microbiol 43(4): 777780

63. Tirawongsaroj P, Sriprang R, Harnpicharnchai P, Taksawan T, Verawat C, Sutipa T, Kusol P, Lily E (2008) Novel thermophilic and thermostable lipolytic enzymes from a Thailand hot spring metagenomic library. J Biotechnol 133:42-49

64. Tong Z, Ruifeng L, Jinyuan S, Yinglu C, Bian W (2020) Characterization and efficient production of a thermostable, halostable and organic solvent-stable cellulase from an oil reservoir. Int J Biol Macromol 159:622-629

65. Valérie D, Mirjam C, Anne B, Christian G, Henri-Pierre F, Jean-Pierre B, Gideon JD, Richard HC (1995) Crystal structure of the catalytic domain of a bacterial cellulase belonging to family 5 . Structure 3:939-949

66. Wang C, Dong D, Wang H, Müller K, Qin Y, Wang H, Wu W (2016) Metagenomic analysis of microbial consortia enriched from compost: New insights into the role of Actinobacteria in lignocellulose decomposition. Biotechnol Biofuels 9(1):22

67. Xiaolin Z, Yongzhen T, Meilu J, Yide L, Gang L (2020) Characterization and purification via nucleic acid aptamers of a novel esterase from the metagenome of paper mill wastewater sediments. Int $J$ Biol Macromol 153:441-450

68. Yuan YL, Zhi YW, Ya TZ, Guo PZ, Ling L (2019) Enzymatic identification and functional sites study of a novel cold-active cellulase (MkCel5) from Microbacterium kitamiensea. Biotechnol Biotec Eq 33:739-747

69. Yun J, Kang S, Park S, Yoon H, Kim MJ, Heu S, Ryu S (2004) Characterization of a novel amylolytic enzyme encoded by a gene from a soil-derived metagenomic library. Appl Environ Microbiol 70:72297235

70. Zheng F, Tu T, Wang XYY, Ma R, Su XXM, Yao B, Luo HY (2018) Enhancing the catalytic activity of a novel GH5 cellulase GtCel5 from Gloeophyllum trabeum CBS 90073 by site-directed mutagenesis on 
loop 6. Biotechnol Biofuels 11:76

71. Zhou JZ, Bruns MA, Tiejie JM (1996) DNA recovery from soils of diverse com position. Appl Environ Microbial 62:316-322

\section{Figures}

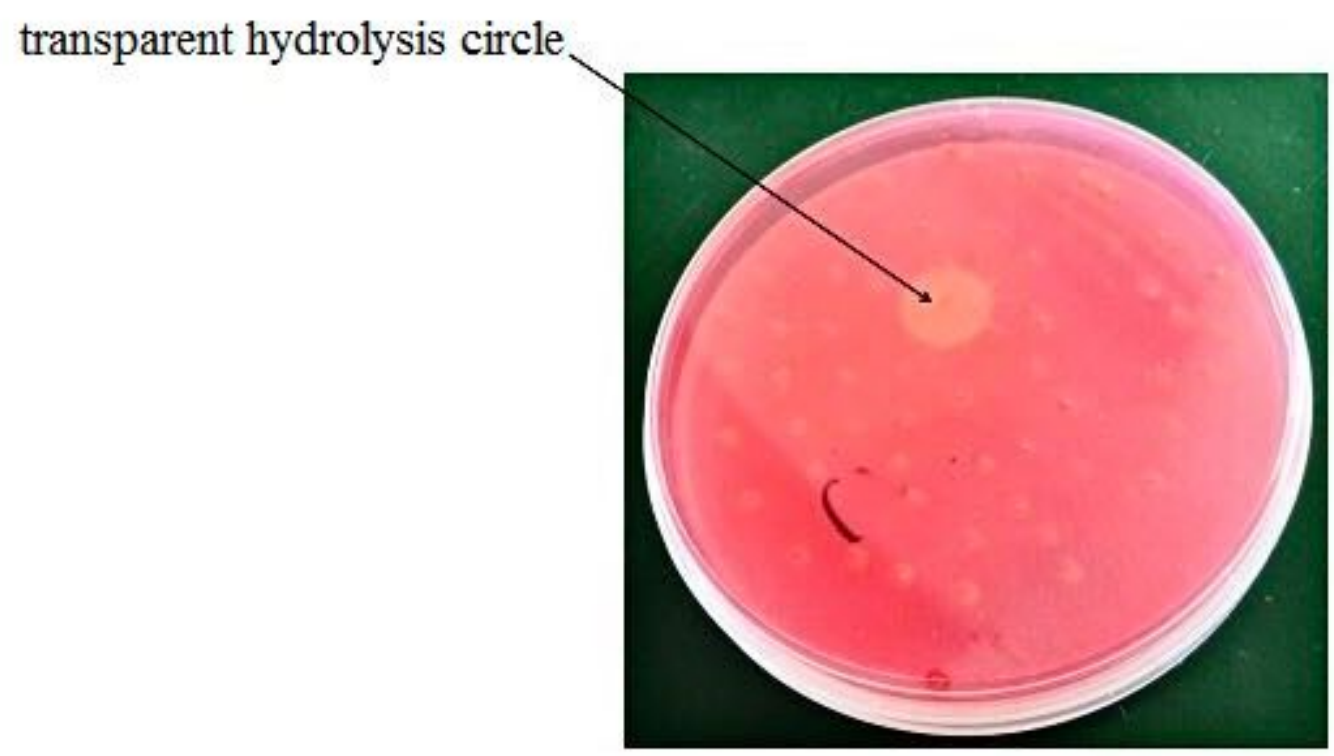

\section{Figure 1}

Screening of the positive clones with cellulase activity. The arrow points to a $1.25 \mathrm{~cm}$ transparent hydrolytic circle 


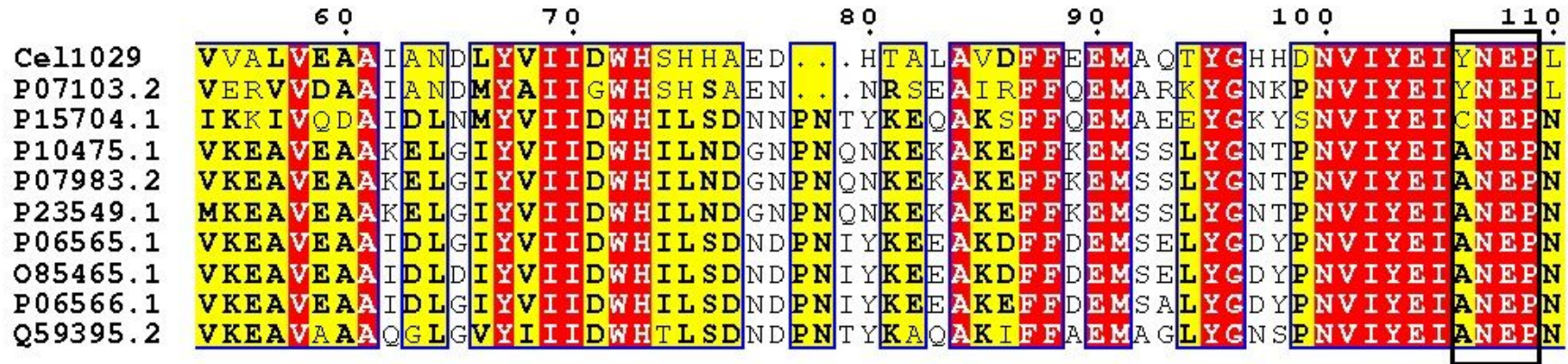
Q59395.2 VKEAVAAAGGLGVYIIIDWHTLSDNDENTYKAOAKIEEAEMAGLYNSENVIYEIANEPN

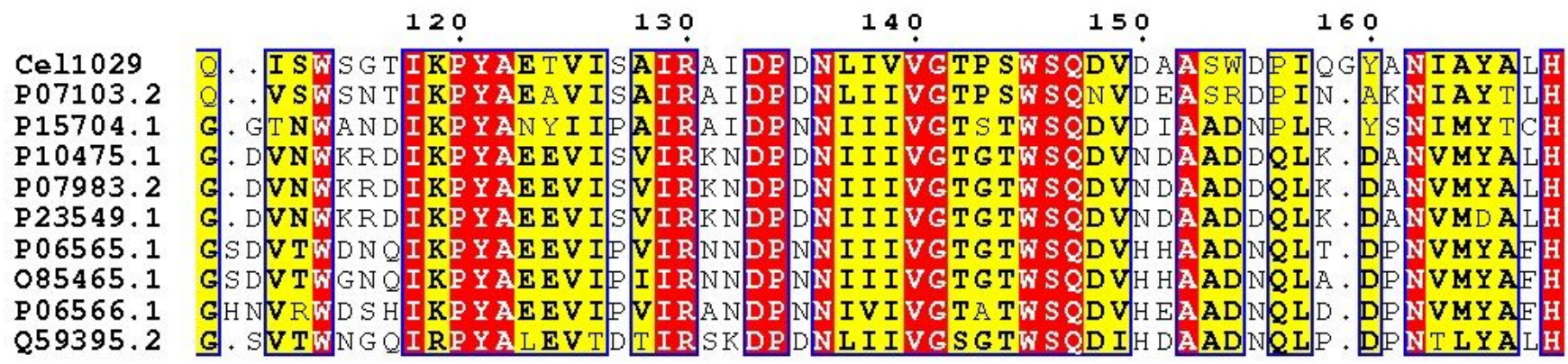

170

180

190

$21 \%$

220

Cel1029

P07103.2

P15704.1

P 10475.1

P07983.2

P23549.1

P 06565. 1

085465.1

P 06566.1

Q59395.2

\begin{tabular}{|c|c|}
\hline 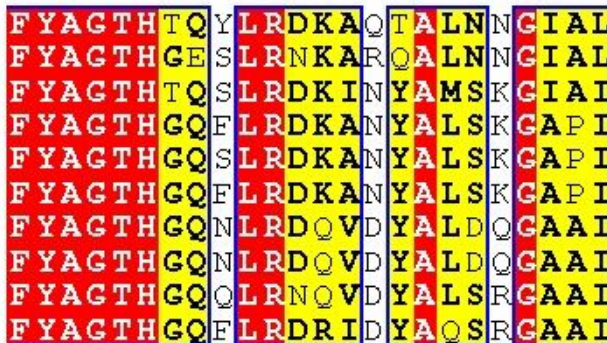 & 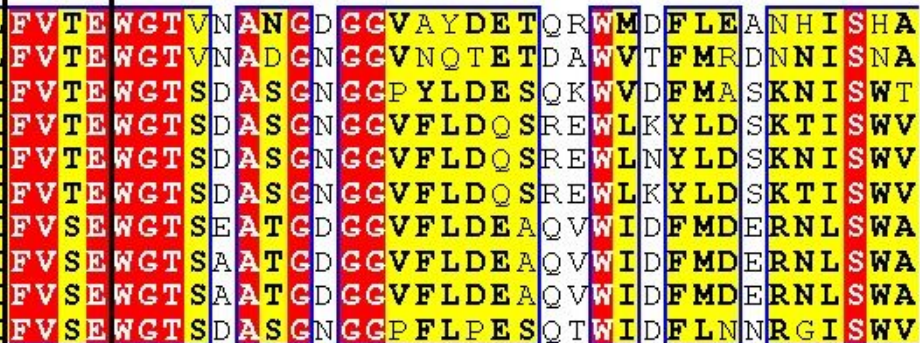 \\
\hline
\end{tabular}

*

\section{Figure 2}

Multiple amino acid sequence alignment of Cel1029 with its closest homologues. Sequences of all closest homologues were obtained from NCBI. Similar sequences were indicated by colored backgrounds. The two catalytic residue sites Glu176 and Glu264 labeled as asterisks(*) were strictly conserved in GH5. P07103.2, P15704.1, 085465.1, Q59395, P10475 \& P07983 \& P23549.1, and P06565 \& P06566.1: endo1,4-D-glucanases from Dickeya dadantii 3937, Clostridium saccharobutylicu, Salipaludibacillus agaradhaerens, Pectobacterium parmentieri, Bacillus subtilis and B. cellulosilyticus respectively. 


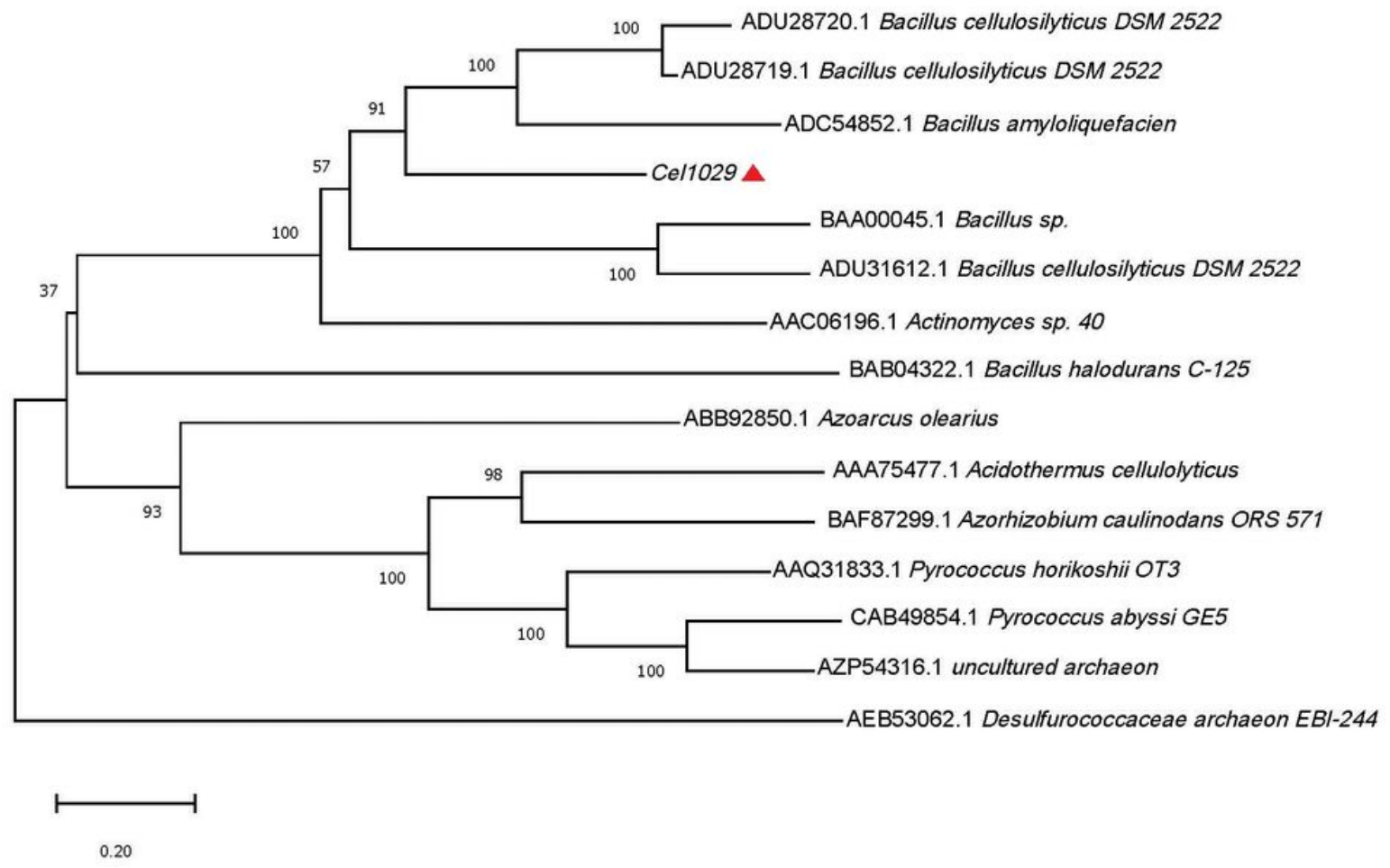

\section{Figure 3}

Phylogenetic tree of Cel1029 and 14 known endoglucanases built by neighbor-joining. Evolutionary history was inferred using neighbor-joining by MEGA-X. Sequences of all endoglucanases were cited from the CAZy. The percentage of replicate trees in which the associated taxa clustered together in the bootstrap test (1000 replicates) is shown next to the branches 


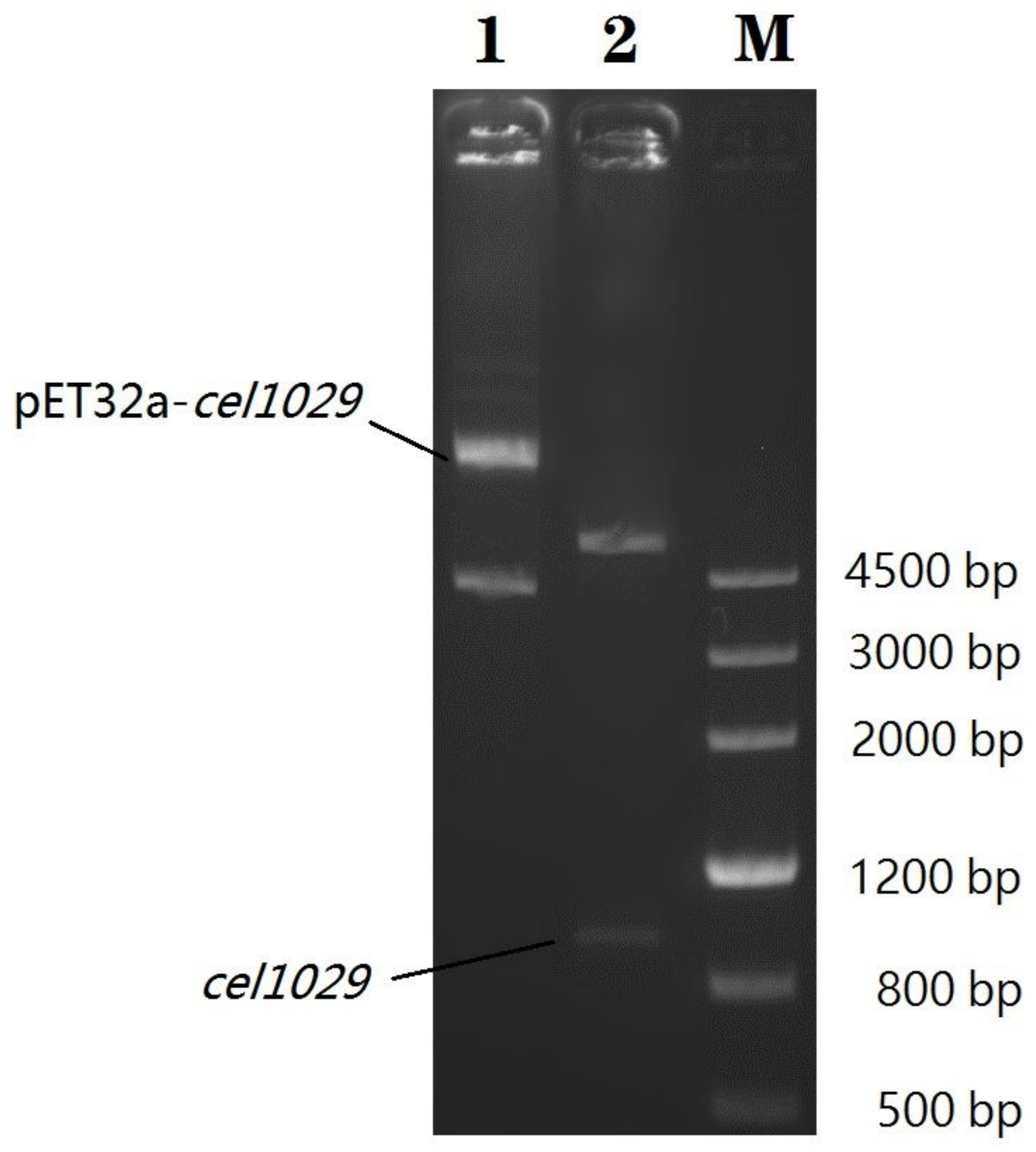

Figure 4

Electrophoresis identification of recombinant plasmid by BamH I and Hind III M, DL45, 00 DNA Marker; Lane 1, Recombinant plasmid; Lane 2, Recombinant plasmid digestion by BamH I and Hind III. The target band is located between 800 and 1200 bp 


\section{$\begin{array}{lll}1 & 2 & M\end{array}$}

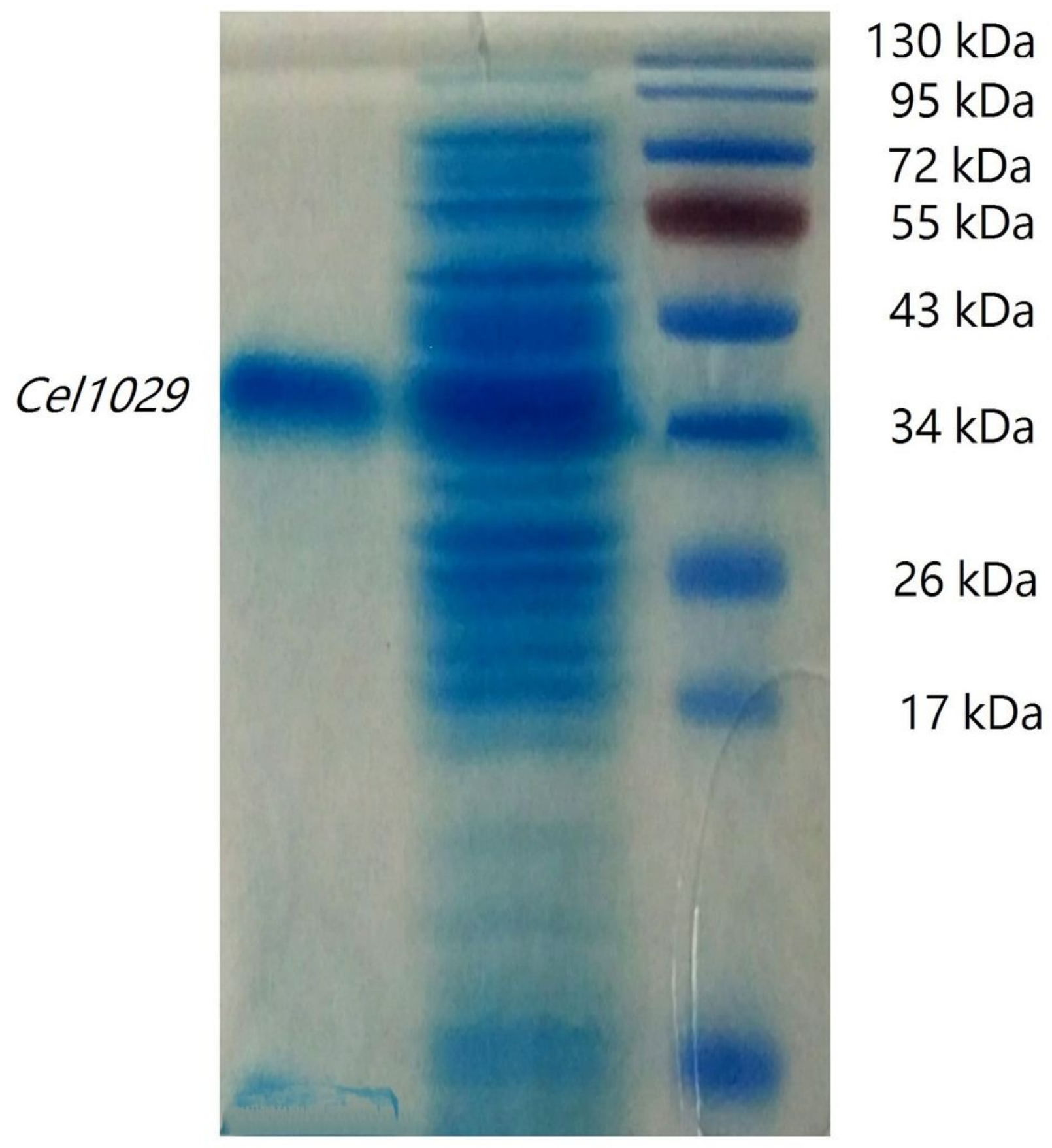

\section{Figure 5}

SDS-PAGE of recombinant Cel1029. M, Protein MW Marker; Lane 1, purified recombinant Cel1029; Lane 2, unpurified recombinant Cel1029. The approximate target band $(37.8 \mathrm{kDa})$ includes the theoretically calculated cellulose enzyme molecular weight (34.21 kDa) and protein molecular tag weight (3.63 kDa) 

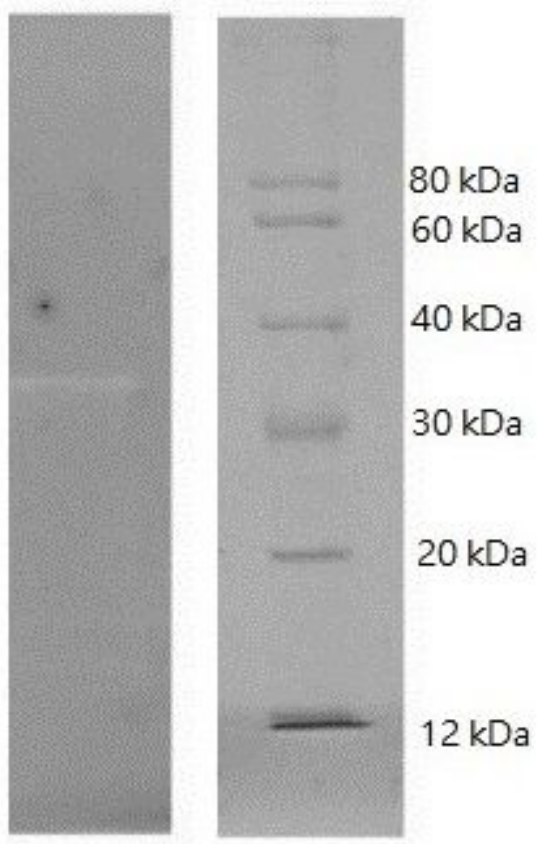

Figure 6

CMC zymogram analysis of purified Cel1029. The translucent zone at about $37.8 \mathrm{kDa}$ indicates that Cel1029 has CMCase activity
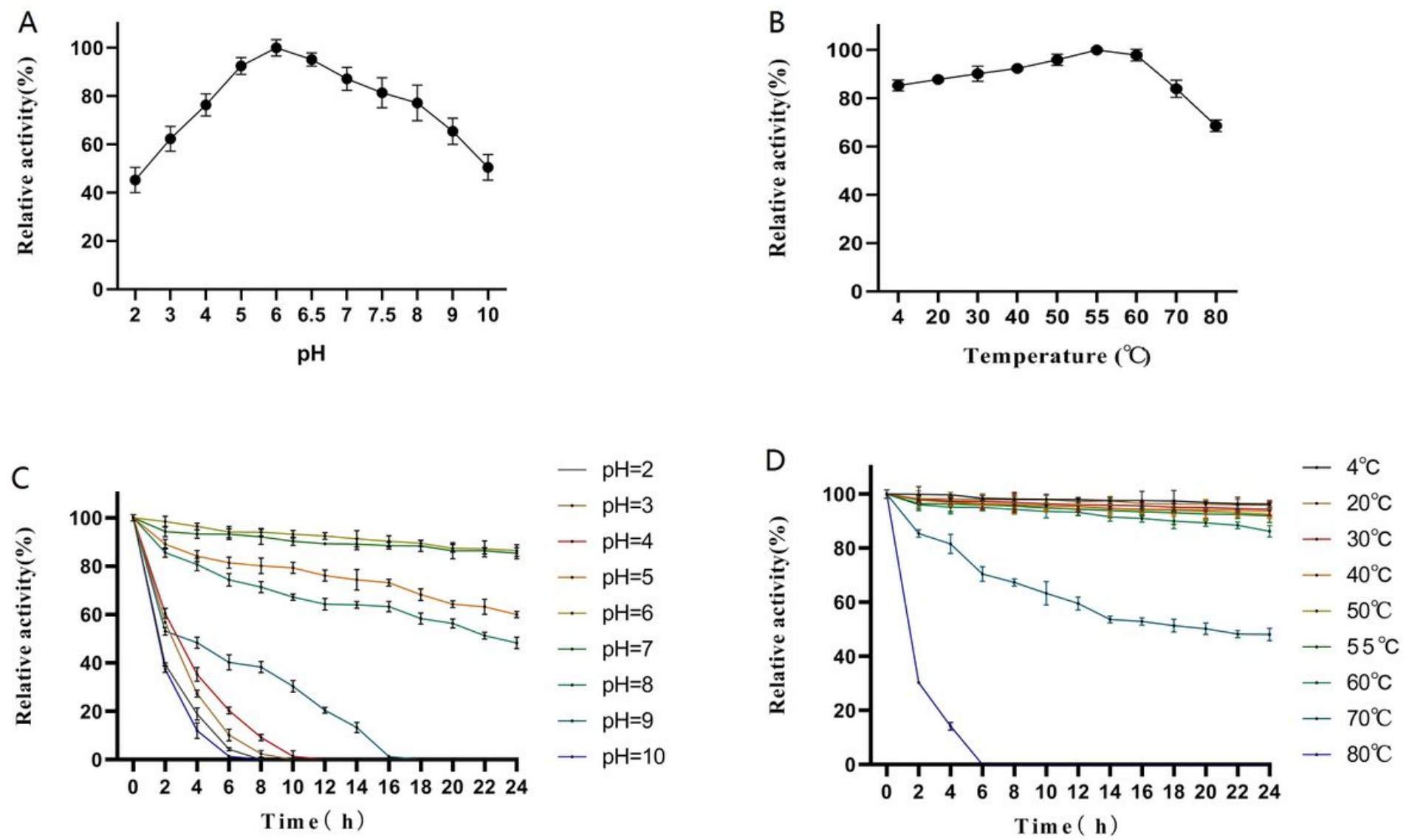
Figure 7

Effects of $\mathrm{pH}$ and temperatures on activity and stability of Cel1029 with CMC as the substrate. Data points and error bars represent mean and standard deviation respectively. (A) Effect of pH on activity of Cel1029 measured after the reaction in $90 \mu \mathrm{L}$ of $40 \mathrm{mM}$ Britton-Robinson (B-R) buffer (pH 2.0-10.0) at 50 ${ }^{\circ} \mathrm{C}$ for 30 min. Enzyme activity at the optimum pH was defined as $100 \%$. (B) Effect of temperature on activity of Cel1029 measured after the reaction in $90 \mu \mathrm{L}$ of $40 \mathrm{mM} \mathrm{B-R}$ buffer $(\mathrm{pH} 6.0)$ from 4 to $80^{\circ} \mathrm{C}$ for $30 \mathrm{~min}$. Enzyme activity at the optimum temperature was defined as $100 \%$. (C) Effect of pH on stability of Cel1029 measured after the reaction in $90 \mu \mathrm{L} 40 \mathrm{mM}$ B-R buffer $(\mathrm{pH} 6.0)$ at $55^{\circ} \mathrm{C}$ for 30 min. Crude enzyme solution prepared with $2 \mathrm{~mL} 40 \mathrm{mM}$ B-R buffer $(\mathrm{pH} 2.0-10.0)$ was stored for $24 \mathrm{~h}$ and taken every $2 \mathrm{~h}$. (D) Effect of temperature on stability of Cel1029 measured after the reaction in $90 \mu \mathrm{L}$ of $40 \mathrm{mM} \mathrm{B}-\mathrm{R}$ buffer ( $\mathrm{pH} \mathrm{6.0)}$ at $55^{\circ} \mathrm{C}$ for $30 \mathrm{~min}$. Pure enzyme solution was stored from 4 to $80^{\circ} \mathrm{C}$ for $24 \mathrm{~h}$ and taken every $2 \mathrm{~h}$. Values are shown as percentage of maximal activity (100\%).

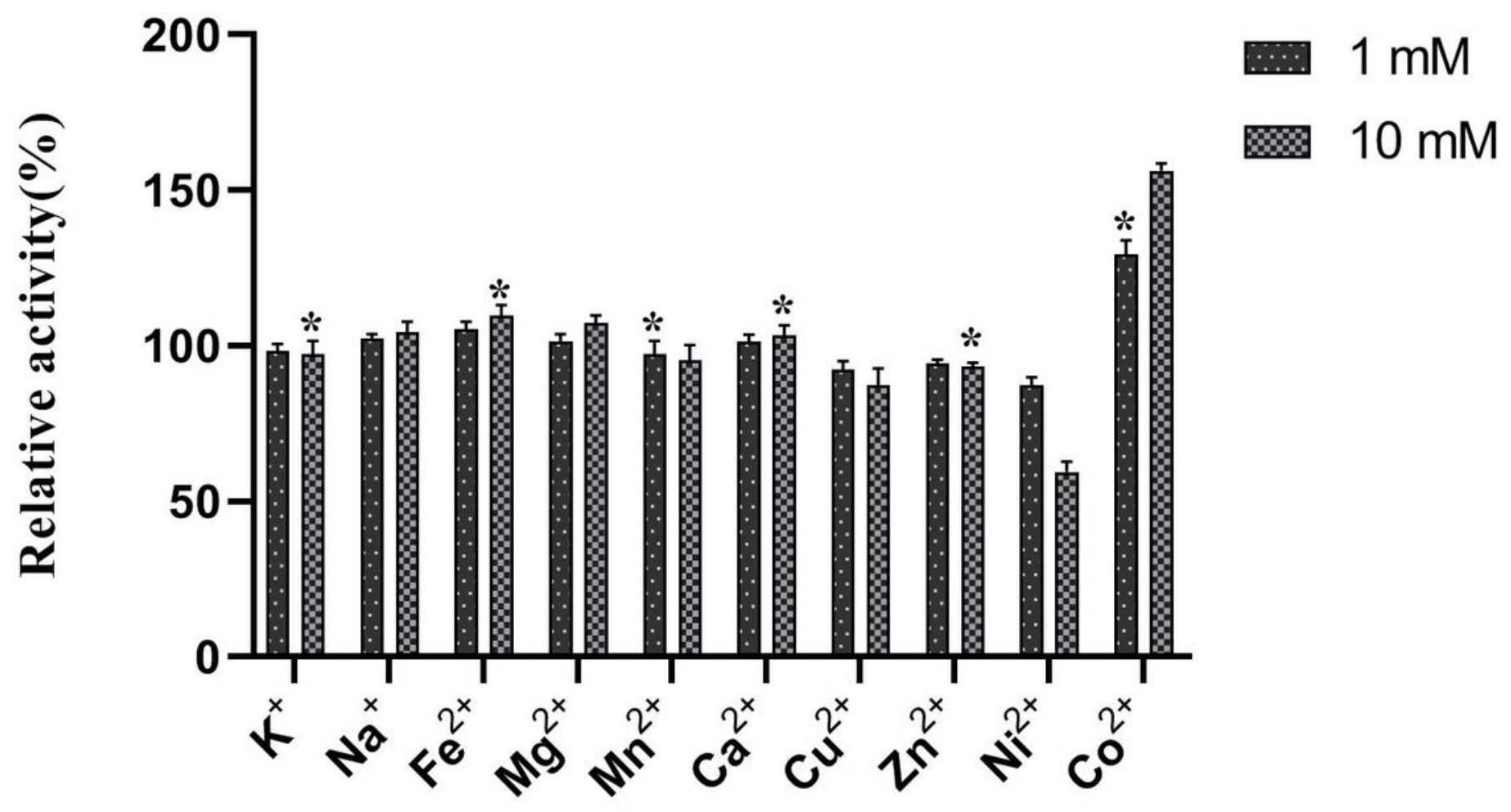

Figure 8

Effects of metal ions on activities of Cel1029 with CMC as the substrate. Enzyme activity was measured after the reaction in $90 \mu \mathrm{L}$ of $40 \mathrm{mM}$ B-R buffer $(\mathrm{pH} 6.0)$ at $55^{\circ} \mathrm{C}$ for $30 \mathrm{~min}$. B-R buffer was added with different metal ions at $1 \mathrm{mM}$ or $10 \mathrm{mM}$. Enzymatic activity without metal ions was defined as $100 \%$ 

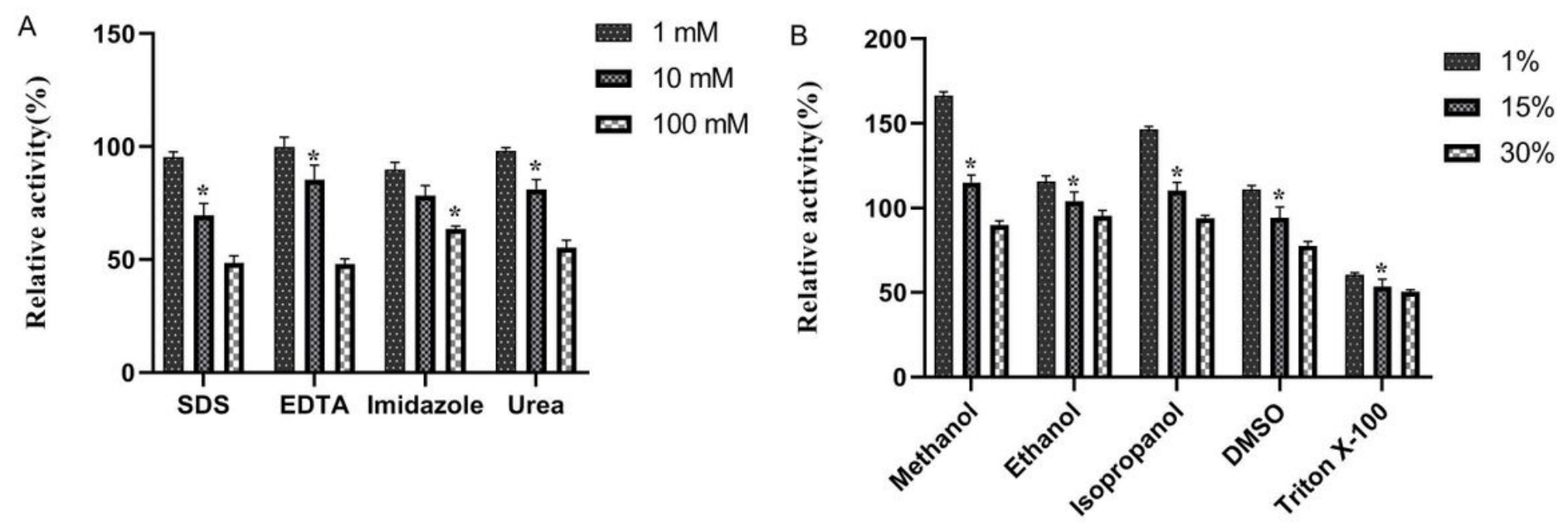

Figure 9

Effects of organic and nonionic solvents on activities of Cel1029 with CMC as the substrate. Enzyme activity was measured after the reaction in $90 \mu \mathrm{L}$ of $40 \mathrm{mM} \mathrm{B}-\mathrm{R}$ buffer $(\mathrm{pH} 6.0)$ at $55^{\circ} \mathrm{C}$ for $30 \mathrm{~min}$. B-R buffer was added with the organic and nonionic solvents at different concentrations. Enzymatic activity without organic and nonionic solvents was defined as $100 \%$ 


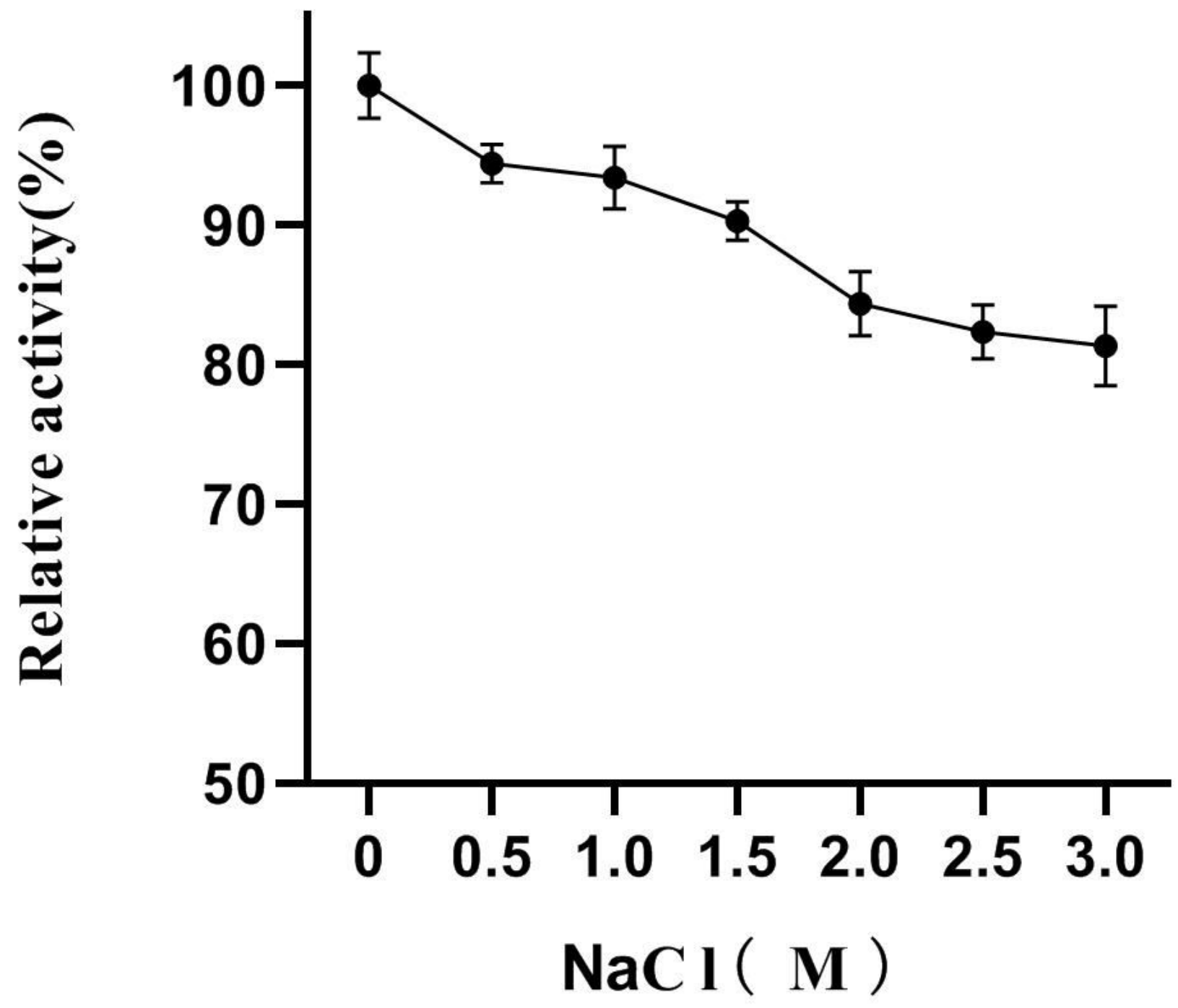

Figure 10

Effects of $\mathrm{NaCl}$ on activities of Cel1029 with $\mathrm{CMC}$ as the substrate. Enzyme activity was measured after the reaction in $90 \mu \mathrm{L}$ of $40 \mathrm{mM} \mathrm{B-R}$ buffer $\left(\mathrm{pH} \mathrm{6.0)}\right.$ ) at $55^{\circ} \mathrm{C}$ for $30 \mathrm{~min}$. B-R buffer was added with $\mathrm{NaCl}$ at different concentrations. Enzymatic activity without $\mathrm{NaCl}$ was defined as $100 \%$ 

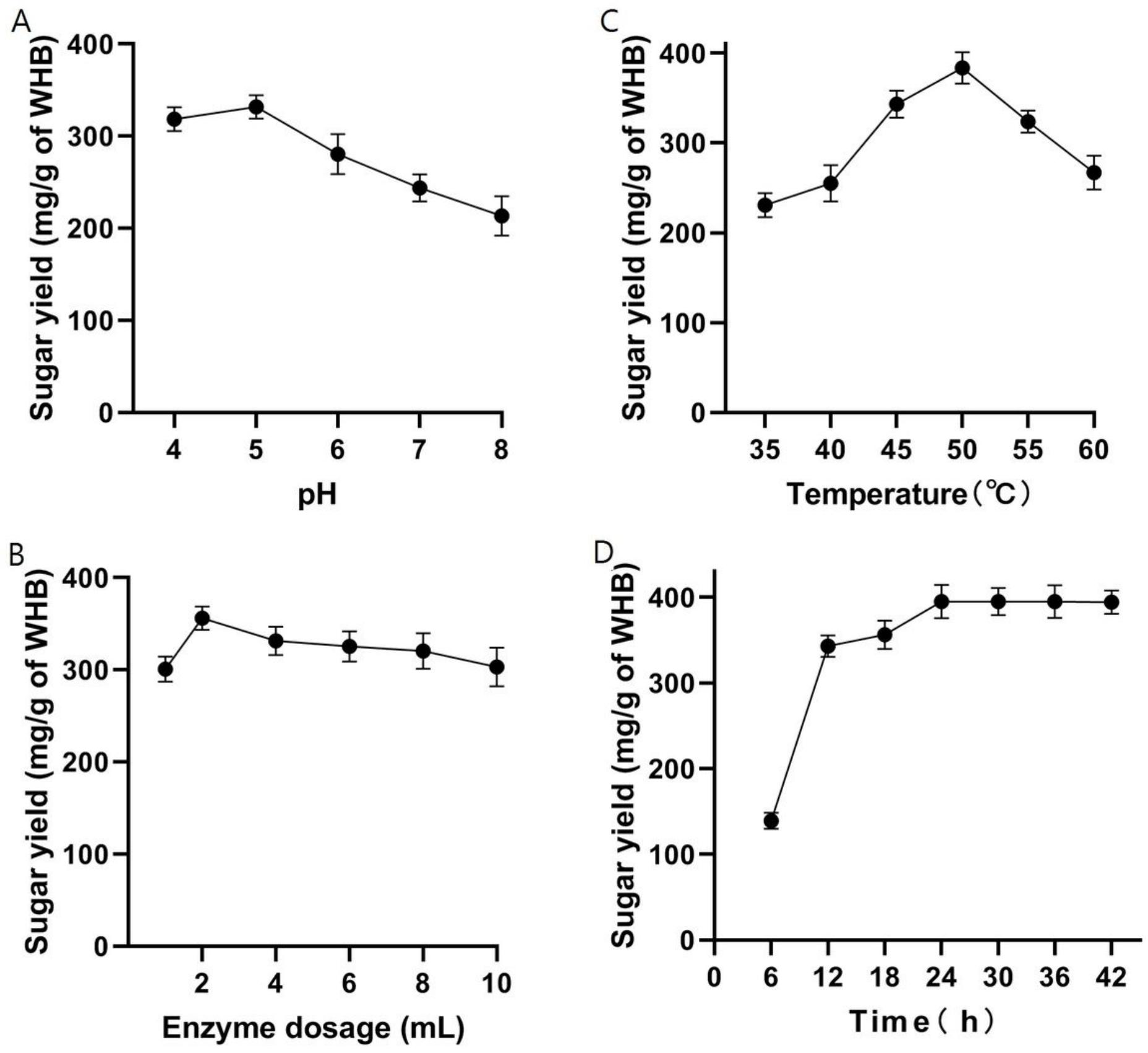

Figure 11

Effects of pH, temperature, enzyme amount and time on enzymatic saccharification of WHB. Data points and error bars represent mean and standard deviation respectively. (A) Effect of pH tested in $40 \mathrm{mM} B-\mathrm{R}$

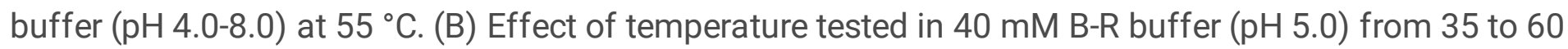
${ }^{\circ} \mathrm{C}$. (C) Effect of enzyme amount tested in $40 \mathrm{mM}$ B-R buffer ( $\mathrm{pH} \mathrm{5.0)}$ ) at $50^{\circ} \mathrm{C}$. (D) Effect of time tested in $40 \mathrm{mM}$ B-R buffer ( $\mathrm{pH} 5.0)$ at $50^{\circ} \mathrm{C}$. Values are shown as reducing sugar yield/WHB quality in reaction systems. Each reaction involved $0.2 \mathrm{~g}$ of WHB and $24.25 \mathrm{U}$ cellulase, and the same amount of an inactivated enzyme solution was used as a negative control 